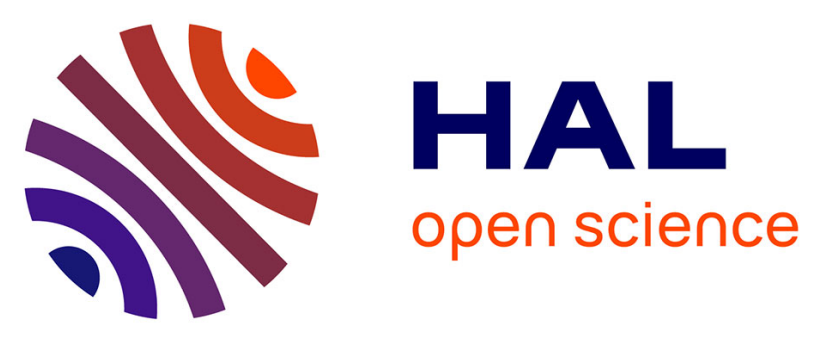

\title{
A first assessment of organic carbon burial in the West Gironde Mud Patch (Bay of Biscay)
}

Nicolas Dubosq, Sabine Schmidt, J P Walsh, Antoine Grémare, Hervé Gillet, Pascal Lebleu, Dominique Poirier, Marie-Claire Perello, Bastien Lamarque, Bruno Deflandre

\section{To cite this version:}

Nicolas Dubosq, Sabine Schmidt, J P Walsh, Antoine Grémare, Hervé Gillet, et al.. A first assessment of organic carbon burial in the West Gironde Mud Patch (Bay of Biscay). Continental Shelf Research, 2021, 221, pp.104419. 10.1016/j.csr.2021.104419 . hal-03337113

\section{HAL Id: hal-03337113 https://hal.science/hal-03337113}

Submitted on 8 Sep 2021

HAL is a multi-disciplinary open access archive for the deposit and dissemination of scientific research documents, whether they are published or not. The documents may come from teaching and research institutions in France or abroad, or from public or private research centers.
L'archive ouverte pluridisciplinaire HAL, est destinée au dépôt et à la diffusion de documents scientifiques de niveau recherche, publiés ou non, émanant des établissements d'enseignement et de recherche français ou étrangers, des laboratoires publics ou privés.

\section{(ㅇ)(1) $\$$}

Distributed under a Creative Commons Attribution - NonCommercial - NoDerivatives| 4.0 
1 A first assessment of organic carbon burial in the West Gironde Mud Patch (Bay of 2 Biscay)

3 Nicolas Dubosq ${ }^{\mathrm{a}^{*}}$, Sabine Schmidt ${ }^{\mathrm{b}}$, J.P. Walsh ${ }^{\mathrm{c}}$, Antoine Grémare ${ }^{\mathrm{a}}$, Hervé Gillet ${ }^{\mathrm{a}}$, Pascal

4 Lebleu $^{\mathrm{a} \dagger}$, Dominique Poirier ${ }^{\mathrm{a}}$, Marie-Claire Perello ${ }^{\mathrm{a}}$, Bastien Lamarque ${ }^{\mathrm{a}}$, Bruno Deflandre ${ }^{\mathrm{a}}$

$5 \quad$ a Univ. Bordeaux, CNRS, EPOC, EPHE, UMR 5805, F-33615 Pessac, France

$6 \quad{ }^{\mathrm{b}}$ CNRS, Univ. Bordeaux, EPOC, EPHE, UMR 5805, F-33615 Pessac, France

$7 \quad{ }^{\mathrm{c}}$ Coastal Resources Center, University of Rhode Island, Kingstown, RI 02881, USA

8 *Correspondence to: UMR 5805 EPOC, Université de Bordeaux, Allée Geoffroy Saint-Hilaire, 933615 Pessac CEDEX, France. E-mail address: nicolas.dubosq@u-bordeaux.fr

\section{Abstract}

11 On the Bay of Biscay continental shelf, there are several mid-shelf mud patches including La 12 Grande Vasière to the north, the West Gironde Mud Patch (WGMP) off the Gironde estuary 13 and the Basque Mud Patch close to the Spanish border. In general, these deposits are several 14 meters thick and cover coarser substrate. Questions remain about their storage capability for 15 fine particles and carbon. This work investigates the sedimentation of the WGMP in order to 16 develop a first estimate of organic carbon (OC) burial. Interface sediment cores were collected 17 at nine stations along two cross-shelf transects in October - November 2016. X-radiograph 18 imaging and grain-size analyses were used to characterize sedimentary structures. ${ }^{210} \mathrm{~Pb}_{\mathrm{xs}}$ depth profiles were established to calculate sediment (SAR) and mass (MAR) accumulation rates. Sedimentary structures indicate episodic sandy inputs overlying older deposits at proximal sites, and relatively continuous sedimentation at seaward locations. On the outer-central portion of the northern transect, a maximum $\operatorname{SAR}\left(0.47 \mathrm{~cm} \mathrm{yr}^{-1}\right)$ was observed, suggesting a depocenter. On the southern transect, excluding two stations where sedimentary inputs appear massive but sporadic, the SARs are lower $\left(<0.3 \mathrm{~cm} \mathrm{yr}^{-1}\right)$. Quantitative estimates of OC burial rates increase seaward with a maximum of $45 \mathrm{gC} \mathrm{m}^{-2} \mathrm{yr}^{-1}$. To evaluate carbon loading independent of grainsize variability, OC values were normalized to surface area of sediments (SA). Interestingly, a qualitative comparison of OC burial efficiencies using the OC/SA ratio highlights three groups of sites (low, medium and relatively high OC burial efficiency) which are likely related both to different sedimentary environments and variable deposition conditions linked to local environmental conditions and depth. This work highlights the likely control of hydrodynamic

31 intensity and sedimentary inputs on the amount of OC stored in the WGMP sediments. 
Keywords: sediment accumulation rate, organic carbon burial, West Gironde Mud Patch, Bay of Biscay, continental shelf

\section{Introduction}

Organic carbon storage in marine sediments is recognized as a long-term sink for atmospheric carbon dioxide (Berner, 1990, 1982). Understanding the ocean carbon cycle and quantifying carbon storage in the oceans are therefore crucial for improving future climate scenarios (Blair and Aller, 2012; Burdige, 2007; Keil, 2017; Muller-Karger, 2005; Włodarska- Kowalczuk et al., 2019). With about $90 \%$ of the modern organic carbon preservation occurring in Riversdominated Ocean Margins (RiOMars) systems (Hedges and Keil, 1995; McKee et al., 2004), special attention should be paid to these areas. Although three types of RiOMars have been defined by Blair and Aller (2012), it can be difficult to understand the nature of an individual system because of high spatial and temporal variability (McKee et al., 2004). Owing to these variabilities, each RiOMar can be divided in several sub-environments where major organic carbon (OC) preservation controlling factors may be different (McKee et al., 2004). Moreover, most studies of RiOMars have focused on tropical systems whose results are difficult to translate to higher latitudes (Yao et al., 2014; Zhu et al., 2016). This explains why, in spite of numerous studies on RiOMars (e.g. Aller, 1998; Aller et al., 1996, 1986; Aller and Blair, 2006; Blair and Aller, 2012; Deng et al., 2006; Kuzyk et al., 2017; McKee et al., 2004; Pastor et al., 2018, 2011; Yao et al., 2014; Zhu et al., 2013 and references therein), mechanisms controlling OC preservation in these environments as well as their carbon burial capabilities are not yet fully understood and quantified.

On the Northeast Atlantic margin, the Bay of Biscay continental shelf extends over more than $1000 \mathrm{~km}$, from the Celtic to the North Iberian margins (Borja et al., 2019; Bourillet et al., 2006; Schmidt et al., 2014). Surface shelf sediments are mainly sand. However on the shelf lie also several mid-shelf mud belts and patches including (1) "La Grande Vasière" to the north, (2) the West Gironde Mud Patch off the Gironde estuary and (3) the Basque Mud Patch in front of San Sebastian and Bayonne (Figure 1, Allen and Castaing, 1977; Jouanneau et al., 2008, 1999; Lesueur et al., 2002). Overall they are of several meters thick and cover coarser substrate (Jouanneau et al., 1999, 1989; Lesueur et al., 2002, 2001). Mud belts and patches are found on many continental shelves around the world. Typically, they are bounded by dynamic sands on their landward side and are the result of river-derived sediment deposition in areas of lower hydrodynamics (i.e., where waves and currents are more reduced on the seabed; McCave, 1972; Walsh and Nittrouer, 2009). Indeed, their mid-shelf location is directly related to the fact that 
higher-energy conditions at shallower depth closer to the coast preclude fine sediment accumulation (Dias et al., 2002; McCave, 1972; Walsh and Nittrouer, 2009). These areas are important for biogeochemical transformations and are known organic carbon sinks (McKee et al., 2004).

The West Gironde Mud Patch is particularly interesting because it is under the influence of the Gironde estuary which is the major source of fine sediments for the Bay of Biscay continental shelf (Constantin et al., 2018; Jouanneau et al., 1999, 1989; Lesueur et al., 2002, 1996, 1991; Weber et al., 1991). Studies led in 1990's have rather well defined its sedimentary functioning and suggested a control of sedimentation and resuspension processes by hydrodynamics (Jouanneau et al., 1989; Lesueur et al., 2002, 1991). Only few studies have focused on the WGMP biogeochemistry and ecology (i.e., Massé et al., 2016; Relexans et al., 1992), and have performed too few measurements to characterize its sedimentological, biogeochemical and ecological functioning. This explains why the capability of the WGMP to store OC has not yet been estimated. The present study aims therefore to characterize sedimentation intensity and preferential areas of sediment accumulation in the WGMP to conduct a first estimate of OC burial rates and efficiencies along two cross-shelf bathymetric transects.

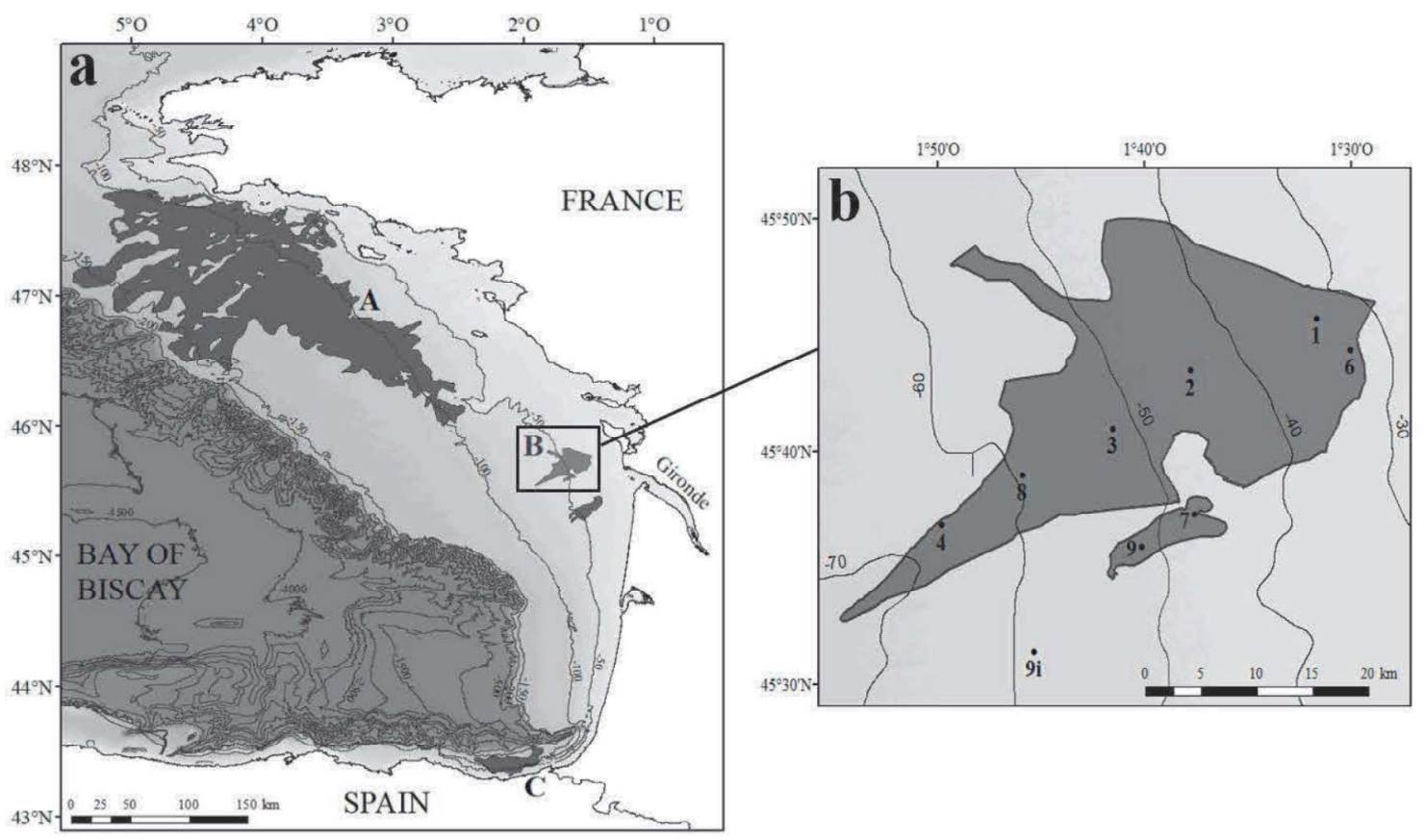

Figure 1: (a) Map of the Bay of Biscay continental shelf with the locations of mud belts and patches: A - La Grande Vasière, B - The Gironde Mud Patches, and C - The Basque Mud Patch. (b) Map of the WGMP showing the location of sampling stations (black circles). The synoptic map of the West Gironde Mud Patch has been determined during the JERICOBENT-5TH cruise (Gillet and Deflandre, 2018) 


\section{Material and methods}

\subsection{Study site}

Formed during the Holocene by filling a depression interpreted as a paleo-valley (Lesueur et al., 2002, 1996), the West Gironde Mud Patch is a silty clay sedimentary patch located in the Bay of Biscay, about $15 \mathrm{~km}$ seaward of the Gironde estuary mouth (Jouanneau et al., 1989). It lies between 30 and $75 \mathrm{~m}$ depth with a surface of about $420 \mathrm{~km}^{2}$ (Jouanneau et al., 1989; Lesueur et al., 1991; Massé et al., 2016). The WGMP is influenced by Gironde inputs (Constantin et al., 2018; Jouanneau et al., 1989; Lesueur et al., 2002), which are the highest during river floods (Constantin et al., 2018; Lesueur et al., 2002). On a historical scale, climatic fluctuations (e.g. the "Little Ice Age") and anthropogenic activities like deforestation during the medieval period or estuary management since the XIX ${ }^{\text {th }}$ century (e.g. dredging, channel hardening) seem to have modified sediment transport processes and therefore the amount of sediments exported to the shelf (Lesueur et al., 2002, 1996). Sediments are transported from the estuary to the WGMP in a benthic nepheloid layer and believed to be deposited in its deeper part (Weber et al., 1991). During their sedimentation, estuarine particles are mixed with biogenic material (e.g. diatoms) produced in the water column (Weber et al., 1991). In the proximal WGMP, sandy inputs from the adjacent continental shelf can be mixed with silt and clay sediments during storm events (Lesueur et al., 2002; Weber et al., 1991).

\subsection{Sampling}

The JERICOBENT-1 cruise took place in October - November 2016 on the R/V Côtes de la Manche (Deflandre, 2016). Undisturbed sediment cores were collected using a MC6 Octopus $\mathrm{GmbH}$ multicorer on two transects (Figure 1). The northern transect includes five stations (1, 2, 3, 8 and 4), and the southern one has four stations (6, 7, 9 and 9i). At each site, three cores were used to characterize sedimentation. A sediment core (core A) was carefully extruded for radioisotope measurements, every $0.5 \mathrm{~cm}$ from the top core to $4 \mathrm{~cm}$ and every $1 \mathrm{~cm}$ below until the core bottom. A second core (core B) was sliced for organic carbon content and sediment surface area measurements every $0.5 \mathrm{~cm}$ over the first centimeter, every $1 \mathrm{~cm}$ until $5 \mathrm{~cm}$ then every $2 \mathrm{~cm}$ until $21 \mathrm{~cm}$ and every $5 \mathrm{~cm}$ below. All the samples were immediately frozen aboard the ship and kept in the freezer until analysis. An additional sediment core was preserved for X-ray imaging (core C), which was performed within a few days after sampling. Due to the thinness of the mud, station 9i was only sampled for radioisotope measurements before repositioning the vessel. 


\subsection{Physical characteristics of sediments}

120 Radiographical images which provide a continuous record of sedimentary structures were performed on a longitudinal section of the preserved sediment core using an X-ray imaging system (SCOPIX). Images recorded were converted in 8 bits to bring out sedimentary structures at high resolution (Lofi and Werber, 2001). Dry bulk density (DBD) was calculated on core A

124 by comparing sediment weight before and after drying at $60^{\circ} \mathrm{C}$ according to the following 125 expression: DBD $=\left(1-\left(\mathrm{V}_{\mathrm{w}} /\left(\mathrm{V}_{\mathrm{w}}+\mathrm{V}_{\mathrm{s}}\right)\right)^{*} \rho\right.$ with $\mathrm{V}_{\mathrm{w}}$ and $\mathrm{V}_{\mathrm{s}}$ respectively volumes of water and 126 particles in the sample and $\rho$, particle density (i.e., $2.65 \mathrm{~g} \mathrm{~cm}^{-3}$ ). Sediment grain-size was 127 measured on cores A and B using a Malvern Mastersizer 2000 laser diffraction particle size 128 analyzer. The grain-size distributions being unimodal with the exception of three samples within sandy layers (i.e. cores B, St. 1: 0.5-1 cm, 1-1.5 cm; St. 4: 20-22 cm), median grain-size (D50) and sand content were used as grain-size descriptors.

\subsection{Radionuclide analysis}

132 The sedimentation framework was determined based on ${ }^{210} \mathrm{~Pb} .{ }^{210} \mathrm{~Pb}\left(\mathrm{~T}_{1 / 2}=22.3\right.$ years $)$ is a 133 naturally-occurring radionuclide continuously delivered by atmospheric fallout and in situ 134 production. This ${ }^{210} \mathrm{~Pb}$, readily scavenged by the particulate phase in the water column and 135 deposited at the seabed by sedimentation, is referred to as ${ }^{210} \mathrm{~Pb}$ in excess $\left({ }^{210} \mathrm{~Pb} \mathrm{xs}_{\mathrm{xs}}\right)$ of that found 136 within sediment due to the decay of its parent isotope, ${ }^{226} \mathrm{Ra}$. Radionuclide activities $\left({ }^{210} \mathrm{~Pb}\right.$,

$137{ }^{226} \mathrm{Ra}$ ) were measured using a high-efficiency, broad energy gamma detector equipped with a 138 Cryo-Cycle II (Mirion). The $\gamma$ detector is calibrated using IAEA certified materials (RGU-1). 139 Errors on activities are based on standard deviation counting statistics. Excess ${ }^{210} \mathrm{~Pb}$ activities 140 were calculated by subtracting the activity supported by its parent, ${ }^{226} \mathrm{Ra}$, from the total ${ }^{210} \mathrm{~Pb}$ activity in the sediment. Sediment layers were measured downcore until reaching negligible ${ }^{210} \mathrm{~Pb}_{\mathrm{xs}}$ activities or the bottom of the core. Sediment and mass accumulation rates (SAR and

144 profiles against depth and cumulative mass, respectively, using the CF:CS (constant flux and 145 constant sedimentation) model.

146 It must be noted that ${ }^{137} \mathrm{Cs}$ could be also detected during the same counting sessions. The 147 occurrence of ${ }^{137} \mathrm{Cs}\left(\mathrm{T}_{1 / 2}=30\right.$ years $)$, an artificial radionuclide, is primarily the result of the 148 nuclear weapon test fallout in the early 1960s. In coastal sediments, its detection is an indicator 149 of sediment deposited since $1950 .{ }^{137} \mathrm{Cs}$ activities present low to negligible activities in WGMP 
sediments, and are not presented in this work. Data (radionuclides, grain-size, dry bulk density) are openly available in a public repository that issues datasets with DOIs (Schmidt, 2020).

\subsection{Particulate organic carbon}

153 OC content was measured on freeze-dried pre-weighed sediments using a LECO CS 200. In

154 order to remove carbonates before analysis, an aliquot of about $100 \mathrm{mg}$ was acidified with $\mathrm{HCl}$

$1552 \mathrm{M}$ and dried at $50^{\circ} \mathrm{C}$ (Cauwet et al., 1990; Etcheber et al., 1999). Sample was then introduced

156 into a furnace where particulate OC combustion produced carbon dioxide which was 157 quantitatively dosed by infrared absorption (Etcheber et al., 1999). The reproducibility of 158 replicated analyses was better than $5 \%$.

159 Organic carbon contents were normalized to surface area of sediments (SA, expressed in $\mathrm{m}^{2} \mathrm{~g}^{-}$

$16{ }^{1}$ ) to minimize variations due strictly to grain-size changes (Hedges and Keil, 1995; Mayer, 161 1994a). A subsample of freeze-dried sediments was first homogenized and degassed overnight 162 at $150^{\circ} \mathrm{C}$. SA was then assessed using a Gemini ${ }^{\circledR}$ VII Surface Area Analyzer (2390a model; 163 Micromeritics ${ }^{\circledR}$ ) by a multi-point BET method (Aller and Blair, 2006; Mayer, 1994a).

\subsection{Statistical treatment}

165 The significance of correlations between median grain-size and surface area of the sediments 166 and between surface area and organic carbon content was assessed using a Spearman's rank 167 correlation coefficient. These analyses were run with the software SigmaPlot version 14.

\section{3. Results}

\subsection{Physical characteristics of sediments and sedimentary structures}

170 Sedimentary environments vary in the WGMP. Indeed, although sediments are mainly silt and 171 clay with a median grain-size of 15-20 $\mu \mathrm{m}$, some peripheral stations (i.e., 1, 6 and 7) have 172 deposits of varying silty and sandy sediments (Figure 2). At these sites, median grain-size is 173 higher than $20 \mu \mathrm{m}$ in some layers of higher sand content ( $>6 \%$, Figure 2). Moreover, the base 174 of these layers is characterized by an erosive contact. The two most proximal stations (i.e., 1 175 and 6) stand out by having a sandy layer on core top. Based on the grain-size profiles and X176 ray images, the thickness of this layer varies from 1 to $4 \mathrm{~cm}$ at station 1 depending on cores, 177 which indicates a high spatial variability in the proximal area. Below this surface layer, median 178 grain-size is rather constant with depth but finer than the size measured at other sites, with 179 values around 12 and $10 \mu \mathrm{m}$ at stations 1 and 6 , respectively. Interestingly, similar finer 180 sediments are observed at station 9 from a depth of $17 \mathrm{~cm}$. X-ray images also highlight the 
181 presence of thin sandy layers at the shallowest stations (i.e., 1, 2, 3, 6, and 7) which become 182 less frequent with increasing depth (Figure 2).

183 The dry bulk density increases in depth on cores with a rather constant grain-size (e.g. stations 1848 and 4, Figure 2) as usually observed in interface sediments because of sediment compaction. 185 On the contrary, DBD profiles show variations, usually related to sandy layers, on cores 1,2 , 186 6, 7 and 9i. These laminae are well preserved in the proximal area (i.e., stations 1 and 6) and at 187 station 7 compared to more distal sites (i.e., 8 and 4) where sediments are homogeneous. The 188 station 9i, at the end of the southern transect is different from the other; it is characterized by a 189 mud deposit of about $14 \mathrm{~cm}$ covering a medium sand substratum (Figure 2). 


\section{Northern transect}

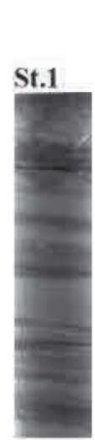

DBD $\left(\mathrm{mg} \mathrm{cm}^{-3}\right)$

D50 $(\mu \mathrm{m})$

$\begin{array}{lllllllll}0.0 & 0.5 & 1.0 & 1.5 & 0 & 25 & 50 & 75 & 100\end{array}$

St.1

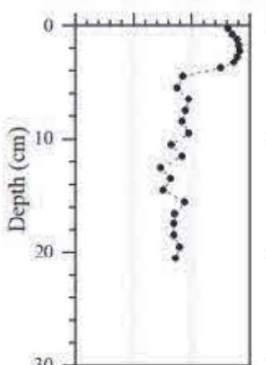

St.2
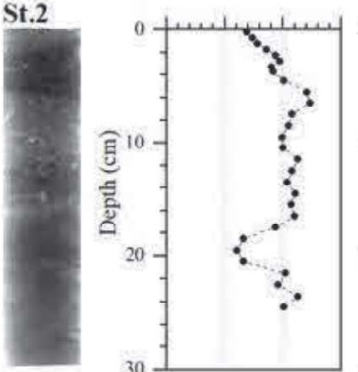

St.3
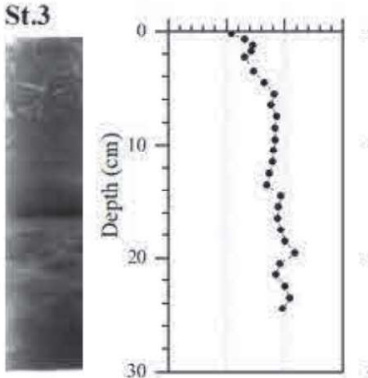

St.8

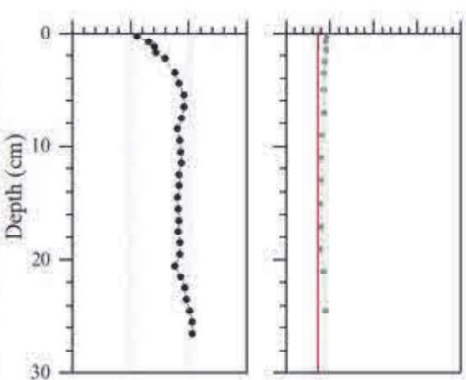

St.4

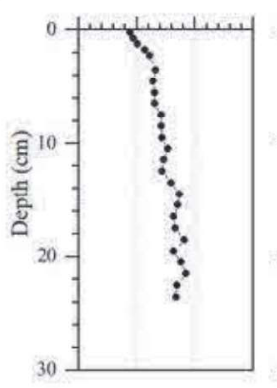

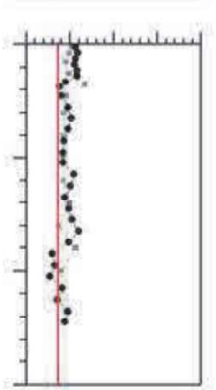
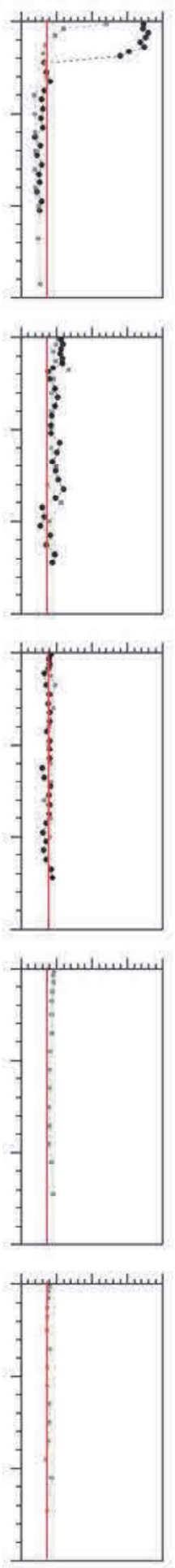

\section{Southern transect}

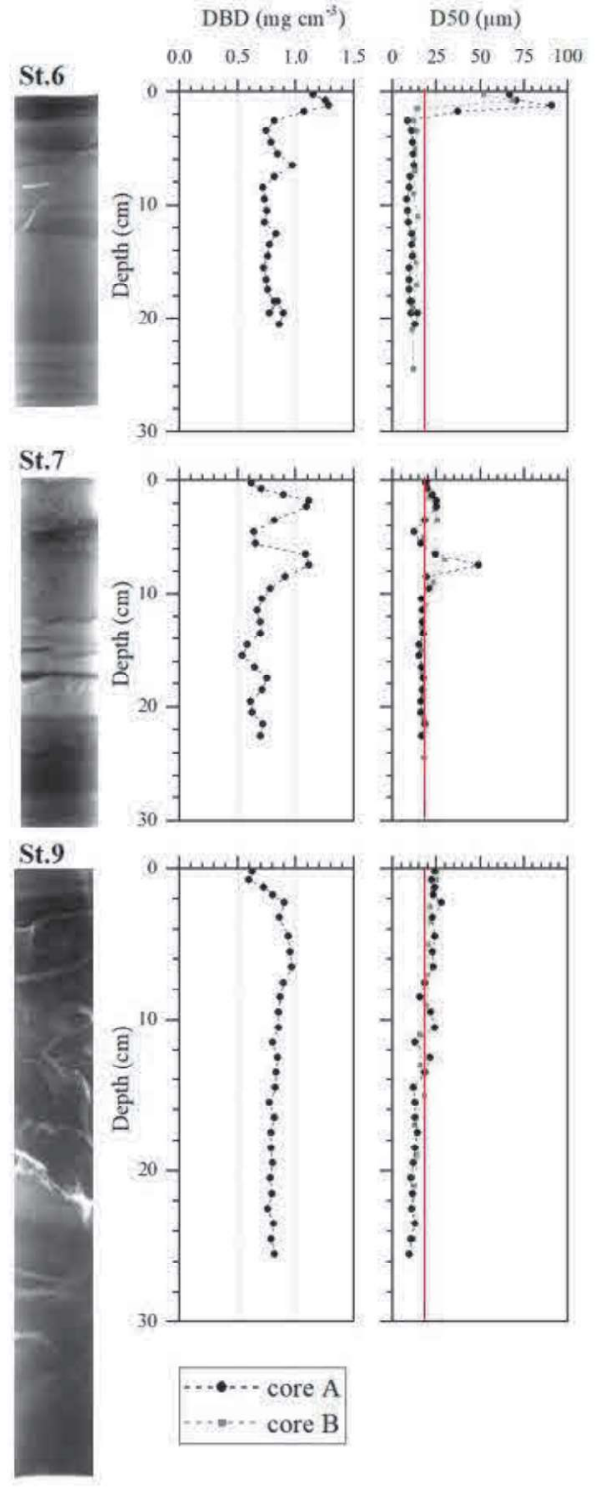

St.9i

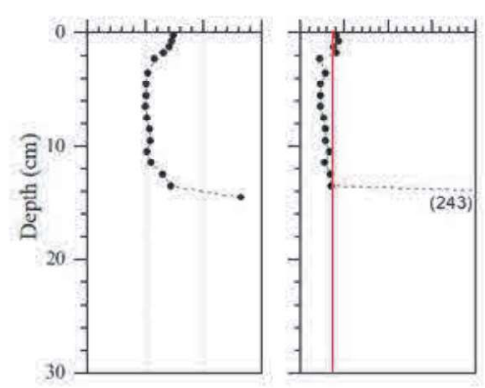

Figure 2: Sedimentary structures: X-ray images and profiles of dry bulk density and median grain-size with depth of cores collecting along the northern (left) and southern (right) transects. The red line defines the background grain-size $(\sim 20 \mu \mathrm{m})$, and in some cases higher sand content is observed $(>6 \%)$. 
195 Along the two depth transects, surface excess ${ }^{210} \mathrm{~Pb}$ ranged between 24 and $111 \mathrm{mBq}^{-1}$, 196 increasing with depth (Figure 3). However, the small difference of depth among sites (affecting 197 water column production) cannot account for such low activities at sites 1 and 6 . Rather, the 198 lower activities are likely due to dilution by sand. There are three types of ${ }^{210} \mathrm{~Pb}_{\mathrm{xs}}$ profiles. The 199 first group corresponds to the proximal stations 1 and 6. The two most proximal stations present 200 low surface activities, associated with sand, and a rapid activities decrease with depth to reach 201 almost supported levels at about $10-15 \mathrm{~cm}$. These profiles reflect rather low mean apparent 202 sediment and mass accumulation rates, about 0.1-0.2 $\mathrm{cm} \mathrm{yr}^{-1}$ and $<200 \mathrm{mg} \mathrm{cm}^{-2} \mathrm{yr}^{-1}$ (Table 1).

203 The second group includes stations 7 and $9 \mathrm{i}$ along the southern transect, and to a less extent 204 station 2 in the north. The cores present evidence of heterogeneities with depth, as revealed by 205 X-ray images, grain-size and dry bulk density (Figure 2, see section 3.1). Such changes in the 206 sediment are likely to impact the ${ }^{210} \mathrm{~Pb}_{\mathrm{xs}}$ activities and are not related to decay. These deep 207 penetration of ${ }^{210} \mathrm{~Pb}_{\mathrm{xs}}$ with depth in the sediment associated with a low activity decrease could 208 reflect massive deposition events. The last group corresponds to cores of the WGMP outer and 209 deepest area, on the north stations 3, 8, and 4 and on the south station 9 . At these stations, ${ }^{210} \mathrm{~Pb}_{\mathrm{xs}}$ 210 profiles present a surface mixed layer, followed by a penetration at depths deeper to $25-30 \mathrm{~cm}$.

211 The mixed layer is comprised from 3-4 $\mathrm{cm}$ at stations 3 and 8 to $8-9 \mathrm{~cm}$ at station 4 , indicating 212 an increase of its thickness with depth. Sediment and mass accumulation rates range between 2130.29 to $0.47 \mathrm{~cm} \mathrm{yr}^{-1}$ and 237 to $438 \mathrm{mg} \mathrm{cm}^{-2} \mathrm{yr}^{-1}$. Along the northern transect, the highest SARs 214 and MARs are observed at mid-depths (around $50 \mathrm{~m}$ ). These results are consistent with the 215 outcome of a first investigation of the WGMP sedimentation, based on less vertically-detailed $216{ }^{210} \mathrm{~Pb}_{\mathrm{xs}}$ profiles established on cores sampled in 1995 (Lesueur et al., 2001). 

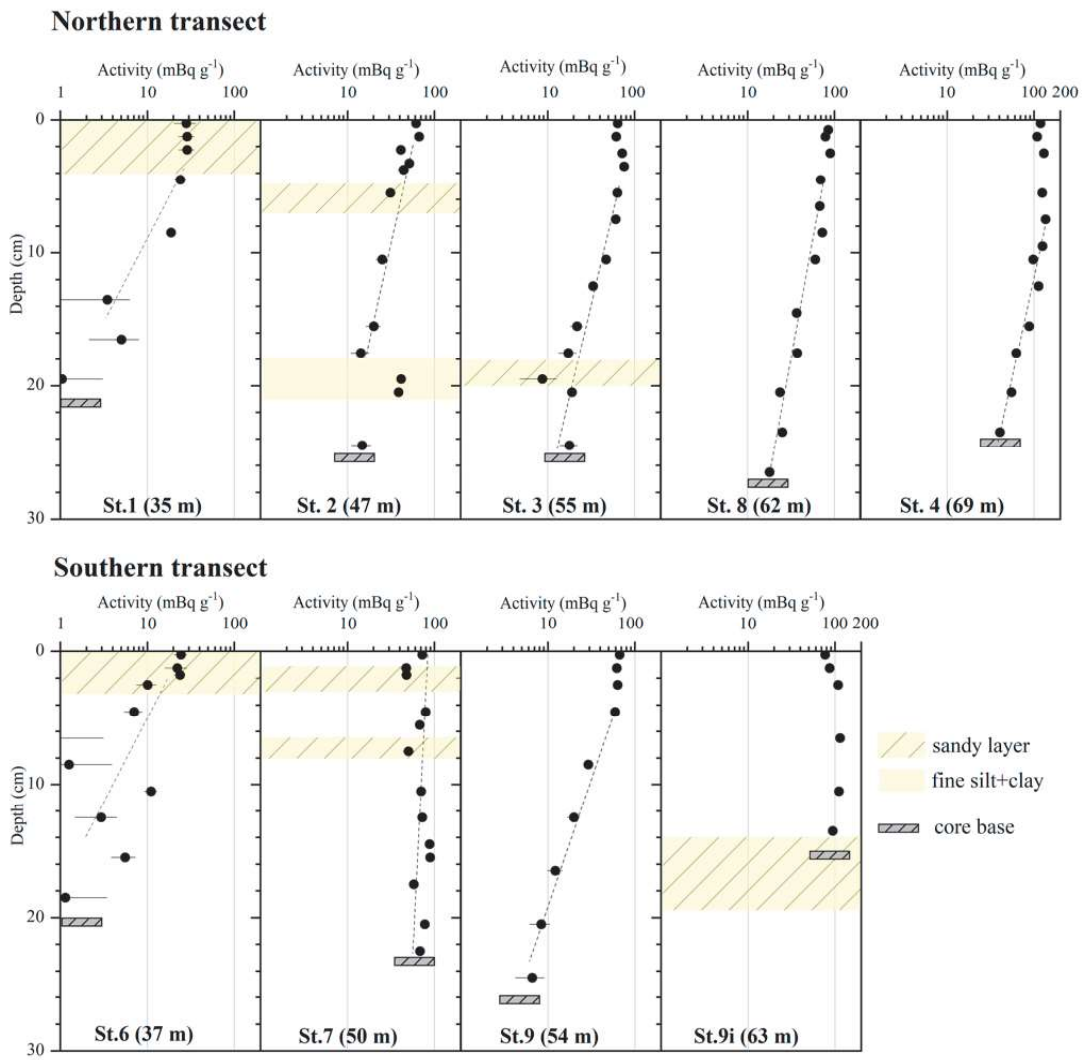

218 Figure 3: Depth profiles of ${ }^{210} \mathrm{~Pb}_{\mathrm{xs}}$ activity for all the sediment cores collected in the West Gironde Mud Patch in fall 2016.

219 Next to the core label, numbers are the water depth at which the cores were collected. Errors bars correspond to 1 SD. The grey 220 rectangle indicates the length of the core.

221 Table 1: Mean bottom OC contents, sediment (SAR) and mass (MAR) accumulation rates calculated from ${ }^{210} \mathrm{~Pb} b_{x s}$ profiles and calculated OC burial rates at nine sites of the West Gironde Mud Patch. For stations 1, 6 and 9, the bottom OC values were taken at the base of modern sediments (see Figure 4)

\begin{tabular}{|c|c|c|c|c|c|c|c|c|c|}
\hline Transect & Stations & $\begin{array}{l}\text { Lat. } \\
{ }^{\circ} \mathrm{N}\end{array}$ & $\begin{array}{l}\text { Long. } \\
{ }^{\circ} \mathrm{E}\end{array}$ & $\begin{array}{c}\text { Depth } \\
\text { m }\end{array}$ & $\begin{array}{c}\text { Bottom OC } \\
\%\end{array}$ & $n=$ & $\begin{array}{l}\text { SAR } \\
\mathrm{cm} \mathrm{yr}^{-1}\end{array}$ & $\begin{array}{c}\text { MAR } \\
\mathrm{mg} \mathrm{cm}{ }^{-2} \mathrm{yr}^{-1}\end{array}$ & $\begin{array}{l}\text { OC burial } \\
\text { rates } \\
\mathrm{gC} \mathrm{m}^{-2} \mathrm{yr}^{-1}\end{array}$ \\
\hline \multirow{5}{*}{ North } & 1 & $45^{\circ} 45^{\prime} 38^{\prime \prime}$ & $-1^{\circ} 31^{\prime} 41^{\prime \prime}$ & 35 & $0.64 \pm 0.03 *$ & 1 & $0.14 \pm 0.08 * *$ & $126 \pm 73^{* *}$ & $8 \pm 5^{* *}$ \\
\hline & 2 & $45^{\circ} 43^{\prime} 45^{\prime \prime}$ & - 1³7'57" & 47 & $0.66 \pm 0.20$ & 5 & $0.48 \pm 0.09 * *$ & $486 \pm 89^{* *}$ & $32 \pm 16$ \\
\hline & 3 & $45^{\circ} 40^{\prime} 58^{\prime \prime}$ & $-1^{\circ} 41^{\prime} 30^{\prime \prime}$ & 55 & $0.99 \pm 0.12$ & 5 & $0.38 \pm 0.04$ & $361 \pm 35$ & $36 \pm 8$ \\
\hline & 8 & $45^{\circ} 38^{\prime} 55^{\prime \prime}$ & $-1^{\circ} 45^{\prime} 48^{\prime \prime}$ & 62 & $1.02 \pm 0.02$ & 5 & $0.47 \pm 0.05$ & $438 \pm 47$ & $45 \pm 6$ \\
\hline & 4 & $45^{\circ} 36{ }^{\prime} 50^{\prime \prime}$ & $-1^{\circ} 49^{\prime} 47^{\prime \prime}$ & 69 & $1.30 \pm 0.04$ & 4 & $0.41 \pm 0.07$ & $338 \pm 56$ & $44 \pm 9$ \\
\hline \multirow{4}{*}{ South } & 6 & $45^{\circ} 44^{\prime} 22^{\prime \prime}$ & - 1³0'2" & 37 & $0.42 \pm 0.27$ & 2 & $0.22 \pm 0.13^{* *}$ & $172 \pm 102 * *$ & $7 \pm 9 * *$ \\
\hline & 7 & $45^{\circ} 37^{\prime} 17^{\prime \prime}$ & - 1³7'34" & 50 & $1.41 \pm 0.19$ & 6 & $0.97 \pm 0.20^{* * *}$ & $648 \pm 122 * * *$ & - \\
\hline & 9 & $45^{\circ} 35^{\prime} 54^{\prime \prime}$ & $-1^{\circ} 40^{\prime} 9^{\prime \prime}$ & 54 & $1.17 \pm 0.10$ & 3 & $0.29 \pm 0.03$ & $237 \pm 22$ & $28 \pm 5$ \\
\hline & $9 \mathrm{i}$ & $45^{\circ} 31^{\prime} 25^{\prime \prime}$ & $-1^{\circ} 45^{\prime} 20^{\prime \prime}$ & 63 & - & - & $2.83^{* * *}$ & $1413 * * *$ & - \\
\hline
\end{tabular}

*analytical incertitude

** apparent maximum SAR, MAR and OC burial rates, presence of sandy layers

*** indicative maximum SAR and MAR - not suitable for calculations 
225 Surface organic carbon contents increase seaward from 0.5 to $1.5 \%$ (Table 2, Figure 4) as

226

227

228

229

230

231

232

233

234

235

236

237

238

239

240

241

242

243

244

245

246

247

previously reported (Massé et al., 2016; Relexans et al., 1992). Depth OC profiles present different patterns depending on sites as reported for ${ }^{210} \mathrm{~Pb}_{\mathrm{xs}}$. Profiles at stations 3 and 8 present the highest values of $\mathrm{OC}$ at the core top which remain rather constant in the mixed layer and then decrease in depth. This pattern is different for stations 1, 2, 6 and 7 which show more erratic profiles where the lowest OC values appear to be associated with sandy layers (Figure 4). Mayer (1994a) demonstrated that the relation between OC content and grain-size is related to the adsorption of organic matter on particles, and this can be reinterpreted in terms of the surface area of sediments. Typically, larger-sized particles such as sands have a smaller surface area than smaller-sized particles such as clays. Less organic matter is therefore adsorbed on sandy sediments than on muddy ones. These patterns are observed for the whole WGMP with significant correlations between grain-size and SA ( $p$-value $<0.01$, Figure 5a) and between SA and OC content (p-value $<0.01$ for the two slopes, Figure 5c), indicating that the sediment OC content is at least partly controlled by the grain-size and surface area of particles.

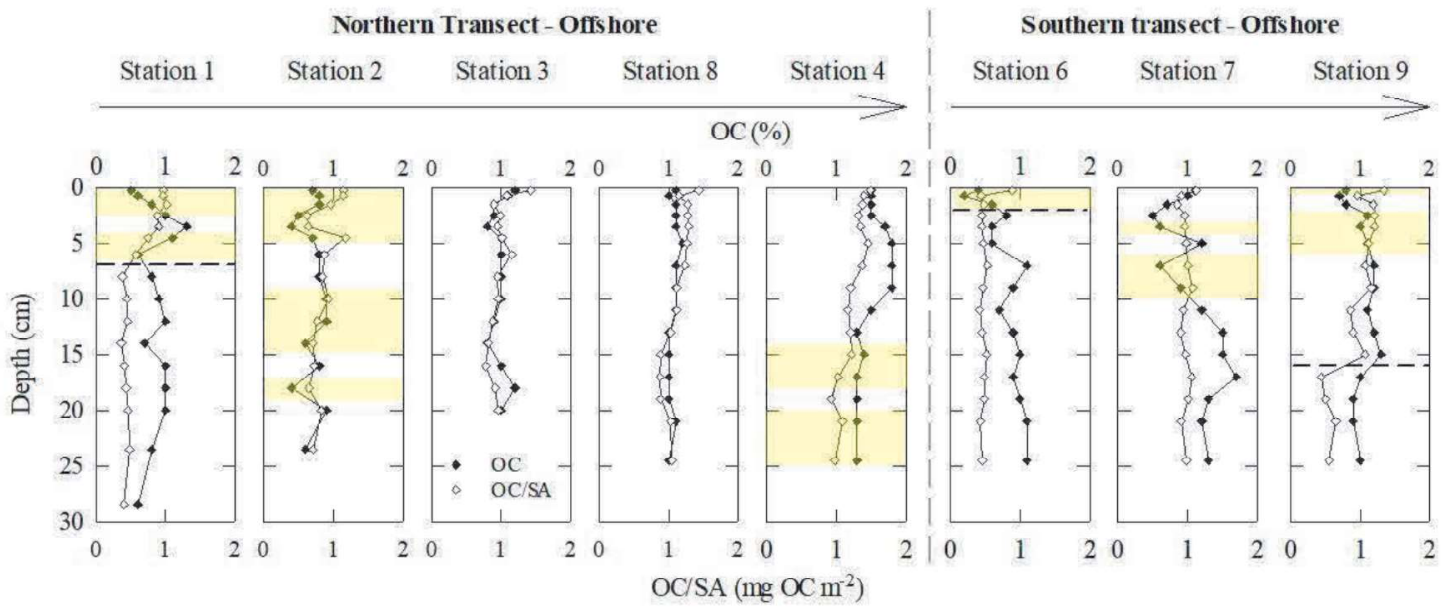

Figure 4: Vertical distributions of $\mathrm{OC}$ content $(\%)$ and $\mathrm{OC} / \mathrm{SA}$ ratio $\left(\mathrm{mgOC} \mathrm{m}^{-2}\right)$ in sediment cores collected in the West Gironde Mud Patch. The yellow stripes indicate the position of noticeable sandy layers. Dashed lines represent the limit between modern and relic deposits.

A classical way to minimize OC content variations strictly related to grain-size changes is to normalized OC values to particle SA (Aller and Blair, 2006; Mayer, 1994a, 1994b). An increase of OC/SA ratios in surface sediments is still observed seaward (Figure 4, Table 2). The profiles of OC/SA ratio show the highest values on cores top followed by a decrease with depth until reaching a quite constant value at cores bottom. Interestingly, a sharp change of the OC/SA 
ratio is observed on profiles of stations 1, 6 and 9 under which they are quite constant (Figure

249 4), suggesting the presence of two distinct vertical horizons in the sediment columns. These 250 deposits stand out from most sediments of the WGMP by a lower median grain-size and a higher 251 SA (Figure 5). Besides, we observed during slicing that these sediments were visually different, 252 i.e. darker and much stickier. These changes can be related to a variation of sediments in term 253 of sources or ages. From these observations, we interpret the sedimentary columns of cores 1 , 2546 and 9 as (1) a top part where modern deposition occurs and (2) a bottom part corresponding 255 to old sediments (Figure 4). In the rest of the text, the two parts of these cores are respectively 256 qualified as "modern" and "relic" deposits.

Table 2: Surface and bottom core OC contents $(\%)$ and $\mathrm{OC} / \mathrm{SA}$ ratio $\left(\mathrm{mgOC} \mathrm{m}^{-2}\right)$. ${ }^{*}$ For stations 1,6 and 9 the bottom values were taken at the base of modern sediments.

\begin{tabular}{cccccc}
\hline \multirow{2}{*}{ Stations (Depth) } & \multicolumn{2}{c}{ OC content (\%) } & \multicolumn{2}{c}{ OC/SA $\left(\mathrm{mgOC} \mathrm{m}^{-2}\right)$} \\
& & Surface & Bottom & Surface & Bottom \\
\hline \multirow{4}{*}{ North } & $1(35 \mathrm{~m})$ & 0.48 & $0.64^{*}$ & 0.97 & $0.57^{*}$ \\
& $2(47 \mathrm{~m})$ & 0.70 & 0.56 & 1.14 & 0.71 \\
& $3(55 \mathrm{~m})$ & 1.15 & 1.02 & 1.42 & 0.96 \\
& $8(62 \mathrm{~m})$ & 1.08 & 1.01 & 1.43 & 1.04 \\
& $4(69 \mathrm{~m})$ & 1.53 & 1.25 & 1.49 & 0.98 \\
& & & & & \\
\multirow{2}{*}{ South } & $7(37 \mathrm{~m})$ & 0.36 & $0.61 *$ & 0.89 & $0.48^{*}$ \\
& $7(50 \mathrm{~m})$ & 1.09 & 1.32 & 1.12 & 0.98 \\
\hline & $9(54 \mathrm{~m})$ & 0.84 & $1.25^{*}$ & 1.34 & $1.07^{*}$ \\
\hline
\end{tabular}

259

260
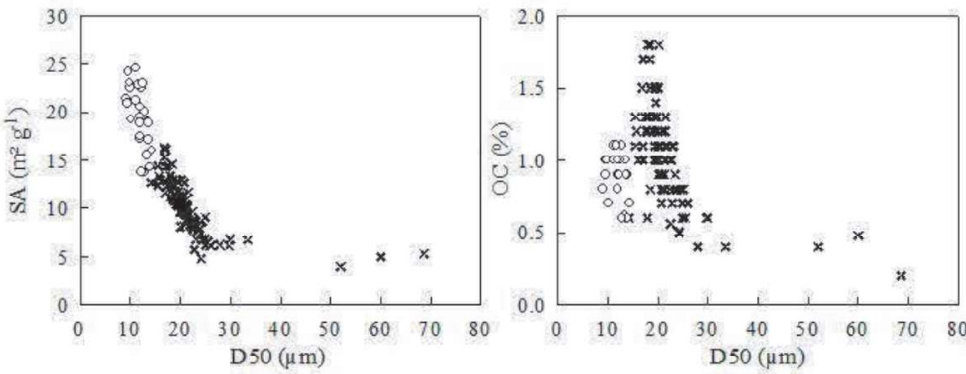
and $0.53 \pm 0.09 \mathrm{mgOC} \mathrm{m}^{-2}$, respectively (Figure 4).

The OC/SA ratios at the base of modern sediments vary by more than twice depending on stations and increase with bathymetry with values of $0.5-0.6 \mathrm{mgOC} \mathrm{m}^{-2}$ at stations 1 and $6,0.6-$ $0.9 \mathrm{mgOC} \mathrm{m}^{-2}$ at station 2, and about $1.0 \mathrm{mgOC} \mathrm{m}^{-2}$ at the other (Figure 4, Table 2). Relic sediments at stations 1,6 and 9 show quite similar OC/SA ratios of $0.42 \pm 0.04,0.47 \pm 0.04$

Figure 5: SA against median grain-size (a); Sediment OC content against median grain-size (b) and SA (c). Cross correspond to all the sediment samples, excluding the relic sediments (white circles; stations 1,6 and 9). 


\section{Discussion}

269 The sedimentary functioning of the WGMP was first investigated in the late 80 s but its

270

271

272

273

274

275

276

277

278

279

280

281

282

283

284

285

286

287

288

289

290

291

292

293

294

295

296

297

298

299

300 capability to store organic carbon on a multi-decennial scale remains still unknown. A prerequisite of establishing estimates of organic carbon burial rates and efficiencies was then to update the present-day sedimentation rates of the area. The potential factors controlling the spatial changes of OC burial rates and storage efficiencies are then discussed, and the capability of the WGMP to store OC is compared to other continental shelfs.

\subsection{Sedimentation in the WGMP}

Sedimentary structures and sedimentation rates in the WGMP suggest a zonation of sedimentary processes in several areas, which differ by hydrodynamic intensity and the constant or transient nature of deposits. The sedimentation appears to be episodic at stations 1, 6, 7 and 9i. In addition, stations 7 and $9 \mathrm{i}$ are characterized by massive but sporadic deposits. The sedimentary sequences of interstratified sand and silt layers observed at the most proximal stations 1 and 6 are hypothesized to be the result of alternations of fine particles inputs during river floods and of sand inputs from the adjacent continental shelf during storms (Jouanneau et al., 1989; Lesueur et al., 2002; Weber et al., 1991). The modern sedimentation in the proximal area is related to the surface sandy layers, silty deposits being merely seasonal and resuspended during high hydrodynamic events (Jouanneau et al., 1989; Lesueur et al., 2001), resulting in the lowest SAR reported for the WGMP (Table 1). According to literature, relic deposits observed at these sites were dated from 3000 (Jouanneau et al., 1989) to few hundred years B.P. (Lesueur et al., 2002). The deeper and central areas are likely less subjected to hydrodynamic forces (i.e., waves and currents) and thus have higher SAR and MAR (Figure 6, Table 1). ${ }^{210} \mathrm{~Pb}$ xs profiles highlight a rather continuous fine sedimentation on the deepest stations of the northern (i.e., 3, 8 and 4) and southern (i.e., 9) transects. SAR of these sites lie a maximum of $0.47 \pm 0.05 \mathrm{~cm} \mathrm{yr}^{-1}$ on the outer-central part of the area, suggesting the presence of a depocenter (Figure 6, Table 1). The station 2 seems to correspond to a transition area between the proximal and the distal part of the mud patch. It is defined by a rather constant sedimentation interspersed by episodic sandy inputs. Besides the difference in laminae preservation among sites indicates a variation of sediment dynamic. Indeed, the laminae preservation at stations 1, 6 and 7 suggests a high frequency of resuspension/deposition events that prevent to observe biological reworking whereas completely bioturbated facies are observed at distal sites (i.e., 8 and 4). From these results, the WGMP can be divided in three sedimentary areas which can be depicted as: (1) a proximal area subjected to a high hydrodynamics with a low sediment deposition, (2) an outer- 
301 central part with a rather constant sedimentation, and (3) patches where deposits seem massive

302 but sporadic.

303

304

305

306

307

308

309

310

311

312

313

314

315

316

317

318

319

320

321

322

\subsection{Quantitative assessment of OC burial rates in the WGMP}

Sedimentation intensity and sediment OC content are known to influence OC storage in sediments (Middelburg, 2019). Therefore, the zonation of sedimentary processes in the WGMP as well as the offshore increase of surface OC content (Figure 6, Table 2) suggest that organic carbon burial rates vary depending on areas.

Mean organic carbon burial rates (BR) were determined by multiplying the sediment mass accumulation rate by the mean sediment OC content at the base of modern deposits (Berner, 1982; Masqué et al., 2002; Mayer, 1994a). The non-steady state of sedimentary processes at stations 7 and 9i, precluded the calculation of OC burial rates at these sites. For stations 1 and 6 where the finest fraction is likely to be resuspended during energetic events, burial rates values must be considered as maximum values for the last decades.

On the northern transect, OC burial rates increase seaward from $8 \pm 5 \mathrm{gC} \mathrm{m}^{-2} \mathrm{yr}^{-1}$ at station 1 to almost constant values of about $44-45 \mathrm{gC} \mathrm{m}^{-2} \mathrm{yr}^{-1}$ at depths deeper than $60 \mathrm{~m}$ (Table 2, Figure 6). Indeed, despite the highest sediment $\mathrm{OC}$ contents at station $4, \mathrm{OC}$ burial rates are equivalent at stations 4 and 8 owing to a higher MAR at station 8 (Table 2, Figure 6). This underlines that sediment accumulation intensity is a major controlling factor of organic carbon sequestration on a multi-decennial scale as already reported for other systems like the Rhône delta (Blair and Aller, 2012; Pastor et al., 2011), the Ganges-Brahmaputra Fan (Blair and Aller, 2012), the Eel shelf (Leithold et al., 2005) and more widely for well-oxygenated marine sediments (Blair and Aller, 2012; Canfield, 1994). However, the fact that 

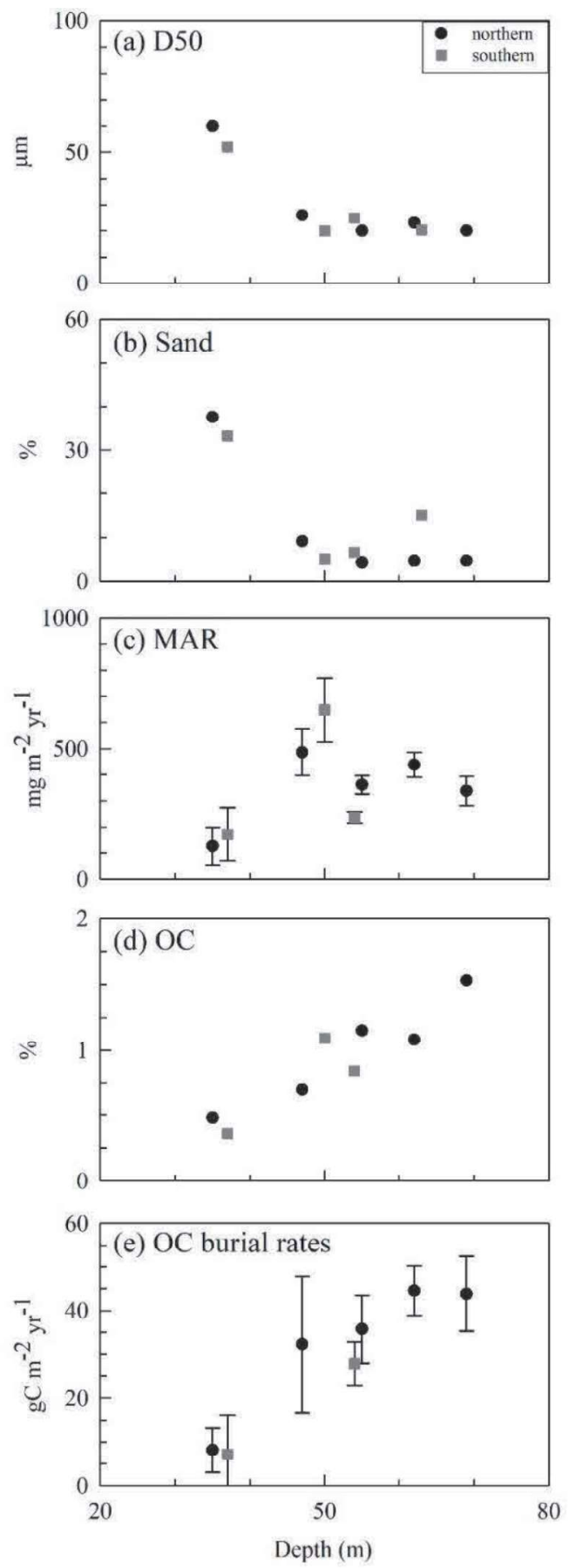

Figure 6: Median grain-size (a), sand (b) and organic carbon (d) content of surface sediments, mass accumulation rates (c) and OC burial rates at multi-decennial scales (e) against water depth of stations along the northern and the southern transects of the West Gironde Mud Patch.

327 OC burial rates are lower at station 2 in spite of an important MAR indicates that burial rates 328 also depend on OC content. It is indeed lower at this station (Table 2) due to the presence of coarser sediments. Organic carbon content at the base of modern deposits is related to (1) organic carbon inputs which are controlled by the type of sedimentation (sand versus mud) and 
to (2) the extent of organic matter degradation (Middelburg, 2019) whose quantification is out

332 the scope of this work. There are three sediment sources to the WGMP: (1) the Gironde estuary

333 whose particles settle mainly in the central and distal areas, (2) a biogenic production in the

334 water column, and (3) the adjacent continental shelf which supplies sand during energetic

335 events (Jouanneau et al., 1989; Lesueur et al., 2002; Weber et al., 1991). On the northern

336 transect, the decrease of surface median grain-size and sand content seaward indicates a

337 decrease of hydrodynamic intensity with depth (Figure 6). This suggests that the type of

338 sedimentation, and so organic matter inputs, are controlled by the hydrodynamic intensity. Sand

339 inputs which occur mainly in the proximal area dilute the sedimentary organic matter whereas

340 higher OC contents are observed in the distal area where hydrodynamic intensity is lower. This

341 clearly shows that the amount of OC stored in the WGMP is influenced by both the amount of

342 sedimentary inputs and hydrodynamic intensity.

3434.3 Qualitative comparison of OC burial efficiency: direct use of OC content and SA

344 The OC burial efficiency is typically assessed with the ratio of OC burial rates to inputs 345 (Burdige, 2007). As these inputs were not quantified in this work, this quantitative approach is 346 ruled out. Nevertheless, the OC/SA ratio allows a qualitative assessment of organic carbon 347 burial efficiencies. Blair and Aller (2012) reported that this ratio can be used to define different 348 types of sedimentary environments (Figure 7). Briefly areas with enhanced organic matter 349 degradation because of frequent sediment remobilization or low sedimentation rates allowing a 350 long oxygen exposure time are characterized by an OC/SA ratio $<0.4 \mathrm{mgOC} \mathrm{m}{ }^{-2}$. On the 351 opposite, an $\mathrm{OC} / \mathrm{SA}>1.0 \mathrm{mgOC} \mathrm{m}^{-2}$ reflects an environment with $\mathrm{OC}$ inputs higher than loss 352 through degradation (e.g. upwelling or low-oxygen areas). Intermediate values between 0.4 and $3531.0 \mathrm{mgOC} \mathrm{m}^{-2}$ are observed on river-suspended particles and non-deltaic shelf. In the West 354 Gironde Mud Patch, values of OC/SA ratios at the base of modern sediments are typical of non355 deltaic continental shelves (Table 2, Figure 7), namely those which do not receive high 356 sedimentary inputs (Blair and Aller, 2012; Mayer, 1994a). These values indicate stable organic357 mineral associations which protect organic matter from microbial decomposition and result in 358 a lower organic matter reactivity and availability for degradation (Blair and Aller, 2012). This 359 can be due to the supply of relatively refractory organic matter from the Gironde (Etcheber et 360 al., 2007) or to the degradation of organic matter in the sediments of the WGMP until reaching 361 an OC/SA value from which the organic carbon is less bioavailable. The increase seaward of $362 \mathrm{OC} / \mathrm{SA}$ ratios at the base of modern sediments indicates an increase of OC storage efficiency 363 (Table 2, Figure 7). This is consistent with the decrease of hydrodynamic intensity which 
364 controls the extent of sediment resuspension. The higher hydrodynamic intensity at proximal

365 sites (i.e., 1 and 6) promotes thus sediment organic matter degradation (Aller, 1998; Aller and

366 Blair, 2006; Yao et al., 2014) and results in a low OC storage efficiency (Table 2, Figure 7).

367 Conversely, OC storage efficiencies are the highest in the central and distal WGMP.

368 Interestingly, in spite of higher OC burial rates at stations 8 and 4 than at station 3 , the three

369 sites seem to be equally efficient to store OC (Figure 7). Since the OC contents in surface

370 sediments are higher at station 4 , this suggests that organic matter degradation is more efficient

371 at this station than at station 3. The discrepancy between OC burial rates and efficiencies

372 indicates that factors controlling the amount of organic carbon stored in sediments are different

373 than those controlling the preservation efficiency. Therefore, if hydrodynamic intensity and the

374 amount of sedimentary inputs control the quantity of sequestrated OC, the intensity of organic

375 matter degradation may at least in part influence its storage efficiency. Regarding its efficiency

376 to store OC, station 2 can merely be considered as "intermediate". The OC storage at station 7

377 appears as efficient as at the distal sites (Figure 7). This is likely due to the massive

378 sedimentation occurring at this station which limits the degradation of organic matter. However,

379 these deposits may be only transients. Accordingly, it is quite difficult to clearly determine from

380 this study if this storage is efficient on a multi-decennial scale.

381

382

383

384

385

386

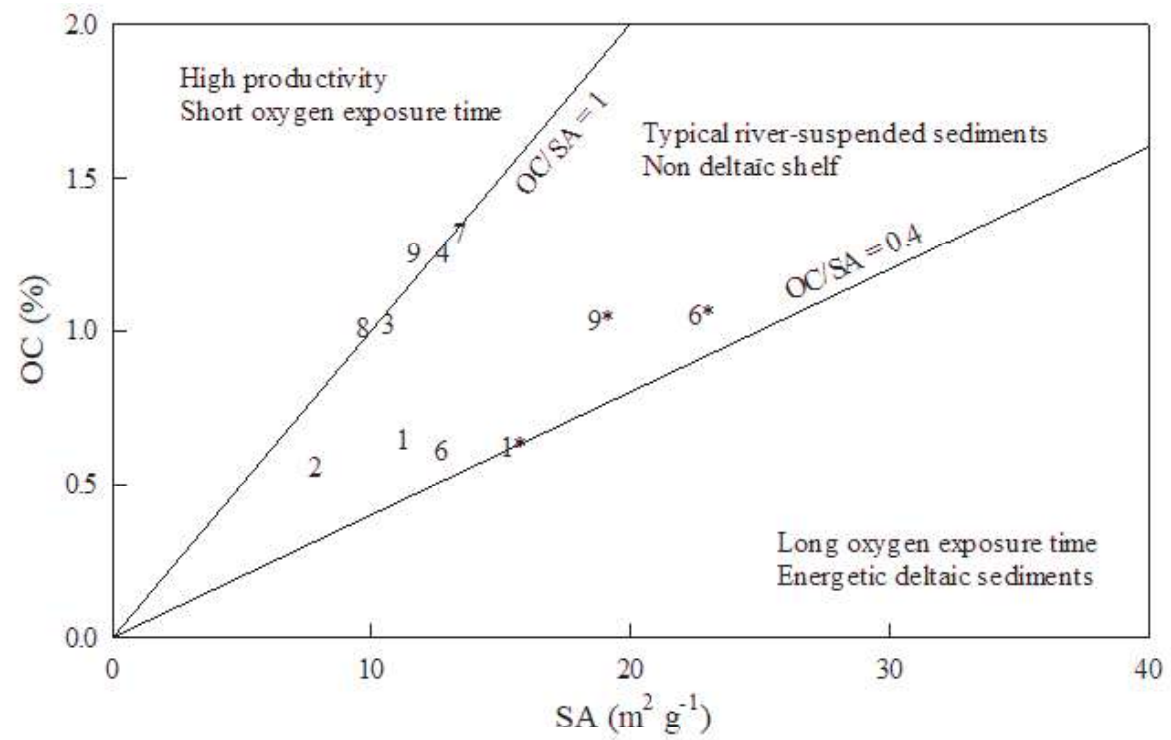

Figure 7: Relationship of OC contents (\%) against surface areas of sediments (SA; $\left.\mathrm{m}^{2} \mathrm{~g}^{-1}\right)$ at the base of modern and relic $(*)$ sediments of the West Gironde Mud Patch. Adapted from Blair and Aller (2012).

Relic deposits at stations 1 and 9 present lower OC/SA ratios than modern ones (Figures 4 and 7). A first explanation is to consider a longer degradation duration. However, ratios of modern and relic deposits are equivalents at station 6. Low and constant OC/SA ratios (Figure 4) 
387 indicate that organic matter has been extensively degraded and reached an OC refractory

388 background (Mayer, 1994b, 1994a). This important degradation observed at stations 1 and 6 is

389 likely related to both degradation duration of organic matter and intense hydrodynamics in the 390 inner WGMP.

391 The use of OC/SA ratios confirms a zonation of sedimentary processes in the WGMP as 392 previously argued on the base of sedimentation characteristics (description, intensity). This

393 could be described in terms of organic carbon storage as: (1) a proximal part characterized by 394 a decimeter-thick modern layer with a relatively low OC storage efficiency overlying relic 395 deposits, (2) a distal area which appears as the only efficient zone for OC storage on a multi396 decennial scale, and (3) patches represented by station 7 where apparent efficient OC storage 397 is likely related to massive sedimentation events. These qualitative estimates of OC burial 398 efficiencies confirm that the OC sequestration in the WGMP depends in part on the 399 hydrodynamic intensity which controls sedimentation and resuspension processes. However, 400 other factors like the intensity of organic matter degradation seem influence OC storage 401 efficiency in the central and distal WGMP.

\section{$402 \quad 4.4$ Comparison with other continental shelves}

403 On the Northeast Atlantic margin, numerous sedimentological and biogeochemical studies have 404 been conducted (Anschutz and Chaillou, 2009; Charbonnier et al., 2019; Herman et al., 2001; 405 Jouanneau et al., 2002; Mouret et al., 2010; Schmidt et al., 2009; van Weering et al., 2002, 406 1998) but only few of them have focused on the OC sequestration in sediments (Epping et al., 407 2002; Mouret et al., 2010; van Weering et al., 2002, 1998). Studies conducted on other areas of 408 the Bay of Biscay margin (Mouret et al., 2010) and on the Celtic (van Weering et al., 1998) and 409 Iberian margins (van Weering et al., 2002), allow a comparison with organic carbon burial 410 rates obtained in the WGMP (this work) (Table 3). There is a wide range of OC burial rates 411 from $<0.5 \mathrm{gC} \mathrm{m}^{-2} \mathrm{yr}^{-1}$ on the Celtic margin (van Weering et al., 1998) to $34.3 \mathrm{gC} \mathrm{m}^{-2} \mathrm{yr}^{-1} \mathrm{on}$ the 412 Iberian shelf (van Weering et al., 2002). Locally, on the Bay of Biscay margin, organic carbon 413 burial rates decrease with increasing depth, with the highest values observed for the WGMP 414 (Table 3). These high OC burial rates are most likely due to the proximity of its main sediment 415 source (i.e., the Gironde). Deeper on the slope, the lower organic carbon burial rates are 416 associated with lower sedimentation rates (Table 3, Mouret et al., 2010). Besides, studies 417 carried out on the Iberian shelf and the Celtic margin (i.e., Epping et al., 2002; van Weering et 418 al., 2002, 1998) concluded that, as for the WGMP, variations of OC burial rates are related to 419 variations of sedimentation intensity. These comparisons highlight that the WGMP is an area 
420 of the Northeast Atlantic margin which stores relatively high amount of organic carbon on a 421 multi-decennial scale.

422 At a global oceanic scale, Blair and Aller (2012) reported and compared organic carbon burial 423 efficiencies of many RiOMars. However quantitative estimates of OC burial rates on 424 continental shelves, where fine sedimentation occurs, are mainly related to systems under the 425 influence of large rivers, with average values from $15.3 \mathrm{gC} \mathrm{m}^{-2} \mathrm{yr}^{-1}$ in the Bohai and Yellow 426 Seas (Hu et al., 2016) to $58.3 \mathrm{gC} \mathrm{m}^{-2} \mathrm{yr}^{-1}$ in the Amazon deltaic shelf(Aller et al., 1996) (Table 427 3). In addition, the spatial extent of these RiOMars (i.e., at least several thousand square 428 kilometers) makes them important areas for organic carbon storage (Aller et al., 1996; Gordon 429 et al., 2001; Hu et al., 2016; Qiao et al., 2017; Sun et al., 2020). Although the WGMP is one 430 with the highest OC burial rates among the Northeast Atlantic margin systems, it cannot be 431 considered as a major sink of organic carbon on a global oceanic scale due to its small spatial 432 extent (i.e., $420 \mathrm{~km}^{2}$ ).

433 Table 3: Mass accumulation rates and OC burial rates in sediments of (1) the West Gironde Mud Patch (this study) (2) the Bay 434 of Biscay (Mouret et al., 2010), (3) the Goban Spur (Celtic margin, Van Weering et al., 1998), (4) the Iberian Margin (Van 435 Weering et al., 2002), (5) the Gulf of Lions shelf (Accornero et al., 2003) and of (6) the Amazon deltaic shelf (Aller et al., 436 1996; Kuehl et al., 1986), the Bohai and Yellow Seas (Hu et al., 2016), the Zhejiang-Fujian Mud Zone (East China Sea, Sun et 437 al., 2020), the inner Louisiana shelf (Gordon et al., 2001). The most proximal sites of the WGMP (i.e., 1 and 6) are not 438 considered. *Average values of organic carbon burial rates.

\begin{tabular}{|c|c|c|c|c|}
\hline Location & $\begin{array}{l}\text { Depth } \\
\text { (m) }\end{array}$ & $\begin{array}{c}\text { MAR } \\
\left(\mathrm{mg} \mathrm{cm}^{-2} \mathrm{yr}^{-1}\right)\end{array}$ & $\begin{array}{c}\text { OC burial rates } \\
\qquad\left(\mathrm{gC} \mathrm{m}^{-2} \mathrm{yr}^{-1}\right)\end{array}$ & References \\
\hline WGMP (Bay of Biscay) & $47-69$ & $237-486$ & $28-45$ & This study \\
\hline Bay of Biscay & 550 & 78 & 7.32 & \\
\hline Bay of Biscay & 1000 & 36 & 2.52 & \\
\hline Bay of Biscay & 1250 & 44 & 2.4 & Mouret et al. (2010) \\
\hline Bay of Biscay & 1500 & 7 & 0.45 & \\
\hline Bay of Biscay & 2000 & 14 & 0.96 & \\
\hline Goban Spur & 208 & $<5.8$ & $>0.16$ & Van Weering et al. (1998) \\
\hline Iberian Margin & 104 & 204.2 & 34.30 & \\
\hline Iberian Margin & 123 & 208.9 & 9.00 & \\
\hline Iberian Margin & 199 & 150.1 & 7.09 & Van Weering et al. (2002) \\
\hline Iberian Margin & 223 & 157.1 & 5.02 & \\
\hline Iberian Margin & 343 & 63.4 & 3.77 & \\
\hline Gulf of Lions & 87 & 230 & 19.0 & Accornero et al. (2003) \\
\hline Amazon deltaic shelf & $9-53$ & $100-6900$ & $58.3^{*}$ & Aller et al. (1996), Kuehl et al. (1986) \\
\hline Bohai and Yellow Seas & $0-400$ & $<100-7000$ & $15.3^{*}$ & Hu et al. (2016) \\
\hline East China Sea & 45.4 & $200-700$ & $41.2^{*}$ & Sun et al. (2020) \\
\hline Louisiana shelf & $4-23$ & $120-450$ & $22.7 *$ & Gordon et al. (2001) \\
\hline
\end{tabular}


440 This study aimed to assess a first estimate of organic carbon sequestration in the West Gironde

441 Mud Patch sediments. The amount of stored OC increases seaward with a maximum value of $44245 \mathrm{gC} \mathrm{m}^{-2} \mathrm{yr}^{-1}$. Beyond the quantification, sedimentary structures and ${ }^{210} \mathrm{~Pb}_{\mathrm{xs}}$ profiles as well as 443 a qualitative comparison of the capability of each site to store OC allow to divide the WGMP 444 in several sedimentary sub-environments: (1) a proximal area where modern deposits are a 445 decimeter-thick layer with a relatively low OC storage efficiency, (2) a distal part with a 446 relatively efficient OC storage and (3) patches where OC storage seems efficient, at least 447 temporarily.

448 The amount of OC sequestrated in sediments on a multi-decennial scale is mainly related to the 449 amount of sedimentary inputs and to hydrodynamic conditions which controls sedimentation 450 intensity and nature (i.e., mud versus sand inputs). However other factors like the intensity of 451 organic matter degradation seem to influence the efficiency of OC preservation in sediments in 452 the central and distal areas. Further studies are therefore need to define and quantify processes 453 which can influence this preservation in the West Gironde Mud Patch on a multi-decennial 454 scale but also on other time scales (seasonal, inter-annual, multi-secular). At the scale of the 455 Northeast Atlantic margin, the West Gironde Mud Patch appears efficient in storing organic 456 carbon but its contribution to the OC storage at larger scale remains quite low because of its 457 small surface area. Nevertheless, considering all mud patches of the Bay of Biscay continental 458 shelf (e.g., La Grande Vasière, the Basque Mud Patch), the OC storage can be potentially 459 significant at the North-Atlantic scale. Accordingly, it appears necessary to led further studies 460 on these areas to define their capabilities to store organic carbon.

\section{Acknowledgements}

462 We sincerely acknowledge the captains and crews of the R/V "Côtes de la Manche" (CNRS463 INSU) for their great help during the JERICOBENT-1 cruise. We also thank Rémy Synais for 464 his work on sampling and analyses as well as François Dano for the preparation of an updated 465 map of the WGMP during his Master 2 dissertation. This work was supported by: (1) the 466 JERICO-NEXT project (European Union's Horizon 2020 Research and Innovation program 467 under grant agreement no. 654410), (2) the VOG project (national program Interface LEFE468 EC2CO). The cruise was funded by the French Oceanographic Fleet (DOI: $46910.17600 / 16010400)$. A doctoral fellowship was provided to N. Dubosq by the french Ministry 470 of Higher Education, Research and Innovation. We are thankful to the French Nouvelle 
Aquitaine Research Council (E3A Project) for co-funding both the low- background gamma detector and the microelectrode system equipped with a camera. We also thank the UMR 5805 EPOC for co-funding the Surface Area Analyzer.

\section{References}

Accornero, A., Picon, P., Bovée, F. de, Charrière, B., Buscail, R., 2003. Organic carbon budget at the sediment-water interface on the Gulf of Lions continental margin. Continental Shelf Research 23, 79-92. https://doi.org/10.1016/S0278-4343(02)00168-1

Allen, G.P., Castaing, P., 1977. Carte de répartition des sédiments superficiels sur le plateau continental du Golfe de Gascogne. Bulletin Institut de Géologie du Bassin d'Aquitaine (Bordeaux) 255-261.

Aller, R.C., 1998. Mobile deltaic and continental shelf muds as suboxic, fluidized bed reactors. Marine Chemistry 61, 143-155. https://doi.org/10.1016/S0304-4203(98)00024-3

Aller, R.C., Blair, N.E., 2006. Carbon remineralization in the Amazon-Guianas tropical mobile mudbelt: A sedimentary incinerator. Continental Shelf Research, Special Issue in Honor of Richard W. Sternberg's Contributions to Marine Sedimentology 26, 2241-2259. https://doi.org/10.1016/j.csr.2006.07.016

Aller, R.C., Blair, N.E., Xia, Q., Rude, P.D., 1996. Remineralization rates, recycling, and storage of carbon in Amazon shelf sediments. Continental Shelf Research 16, 753-786. https://doi.org/10.1016/0278-4343(95)00046-1

Aller, R.C., Mackin, J.E., Cox, R.T., 1986. Diagenesis of Fe and S in Amazon inner shelf muds: apparent dominance of $\mathrm{Fe}$ reduction and implications for the genesis of ironstones. Continental Shelf Research 6, 263-289. https://doi.org/10.1016/0278-4343(86)900646

Anschutz, P., Chaillou, G., 2009. Deposition and fate of reactive Fe, Mn, P, and C in suspended particulate matter in the Bay of Biscay. Continental Shelf Research 29, 1038-1043. https://doi.org/10.1016/j.csr.2008.12.022

Berner, R.A., 1990. Atmospheric Carbon Dioxide Levels Over Phanerozoic Time. Science 249, 1382-1386. https://doi.org/10.1126/science.249.4975.1382

Berner, R.A., 1982. Burial of organic carbon and pyrite sulfur in the modern ocean; its geochemical and environmental significance. American Journal of Science 282, 451473. https://doi.org/10.2475/ajs.282.4.451

Blair, N.E., Aller, R.C., 2012. The Fate of Terrestrial Organic Carbon in the Marine Environment. Annual Review of Marine Science 4, 401-423. https://doi.org/10.1146/annurev-marine-120709-142717

Borja, A., Amouroux, D., Anschutz, P., Gómez-Gesteira, M., Uyarra, M.C., Valdés, L., 2019. The Bay of Biscay, in: World Seas: An Environmental Evaluation. Elsevier, pp. 113152. https://doi.org/10.1016/B978-0-12-805068-2.00006-1

Bourillet, J.-F., Zaragosi, S., Mulder, T., 2006. The French Atlantic margin and deep-sea submarine systems. Geo-Marine Letters 26, 311-315. https://doi.org/10.1007/s00367006-0042-2

Burdige, D.J., 2007. Preservation of Organic Matter in Marine Sediments: Controls, Mechanisms, and an Imbalance in Sediment Organic Carbon Budgets? Chemical Reviews 107, 467-485. https://doi.org/10.1021/cr050347q

Canfield, D.E., 1994. Factors influencing organic carbon preservation in marine sediments. Chemical Geology 114, 315-329. https://doi.org/10.1016/0009-2541(94)90061-2

Cauwet, G., Gadel, F., de Souza Sierra, M.M., Donard, O., Ewald, M., 1990. Contribution of the Rhône River to organic carbon inputs to the northwestern Mediterranean Sea. 
Charbonnier, C., Mouret, A., Howa, H., Schmidt, S., Gillet, H., Anschutz, P., 2019. Quantification of diagenetic transformation of continental margin sediments at the Holocene time scale. Continental Shelf Research 180, 63-74. https://doi.org/10.1016/j.csr.2019.04.015

Constantin, S., Doxaran, D., Derkacheva, A., Novoa, S., Lavigne, H., 2018. Multi-temporal dynamics of suspended particulate matter in a macro-tidal river Plume (the Gironde) as observed by satellite data. Estuarine, Coastal and Shelf Science 202, 172-184. https://doi.org/10.1016/j.ecss.2018.01.004

Deflandre B., 2016. JERICOBENT-1 cruise, Côtes De La Manche R/V. https://doi.org/10.17600/16010400

Deng, B., Zhang, J., Wu, Y., 2006. Recent sediment accumulation and carbon burial in the East China Sea. Global Biogeochemical Cycles 20. https://doi.org/10.1029/2005GB002559

Dias, J.M.A., Jouanneau, J.M., Gonzalez, R., Araújo, M.F., Drago, T., Garcia, C., Oliveira, A., Rodrigues, A., Vitorino, J., Weber, O., 2002. Present day sedimentary processes on the northern Iberian shelf. Progress in Oceanography, Benthic processes and dynamics at the NW Iberian Margin: results of the OMEX II Program 52, 249-259. https://doi.org/10.1016/S0079-6611(02)00009-5

Epping, E., van der Zee, C., Soetaert, K., Helder, W., 2002. On the oxidation and burial of organic carbon in sediments of the Iberian margin and Nazaré Canyon (NE Atlantic). Progress in Oceanography 52, 399-431. https://doi.org/10.1016/S00796611(02)00017-4

Etcheber, H., Relexans, J.-C., Beliard, M., Weber, O., Buscail, R., Heussner, S., 1999. Distribution and quality of sedimentary organic matter on the Aquitanian margin (Bay of Biscay). Deep Sea Research Part II: Topical Studies in Oceanography 46, 2249-2288. https://doi.org/10.1016/S0967-0645(99)00062-4

Etcheber, H., Taillez, A., Abril, G., Garnier, J., Servais, P., Moatar, F., Commarieu, M.-V., 2007. Particulate organic carbon in the estuarine turbidity maxima of the Gironde, Loire and Seine estuaries: origin and lability. Hydrobiologia 588, 245-259. https://doi.org/10.1007/s10750-007-0667-9

Gillet, H., Deflandre, B., 2018. JERICOBENT-5-TH cruise,Thalia R/V. https://doi.org/10.17600/18000425

Gordon, E.S., Goñi, M.A., Roberts, Q.N., Kineke, G.C., Allison, M.A., 2001. Organic matter distribution and accumulation on the inner Louisiana shelf west of the Atchafalaya River. Continental Shelf Research 21, 1691-1721. https://doi.org/10.1016/S02784343(01)00021-8

Hedges, J.I., Keil, R.G., 1995. Sedimentary organic matter preservation: an assessment and speculative synthesis. Marine Chemistry 49, 81-115. https://doi.org/10.1016/03044203(95)00008-F

Herman, P.M.J., Soetaert, K., Middelburg, J.J., Heip, C., Lohse, L., Epping, E., Helder, W., Antia, A.N., Peinert, R., 2001. The seafloor as the ultimate sediment trap-using sediment properties to constrain benthic-pelagic exchange processes at the Goban Spur. Deep Sea Research Part II: Topical Studies in Oceanography 48, 3245-3264. https://doi.org/10.1016/S0967-0645(01)00039-X

Hu, L., Shi, X., Bai, Y., Qiao, S., Li, L., Yu, Y., Yang, G., Ma, D., Guo, Z., 2016. Recent organic carbon sequestration in the shelf sediments of the Bohai Sea and Yellow Sea, China. Journal of Marine Systems 155, 50-58. https://doi.org/10.1016/j.jmarsys.2015.10.018 
601

602

603

604

605

606

607

608

609

610

611

612

613

614

615

616

Jouanneau, J.-M., Weber, O., Champilou, N., Cirac, P., Muxika, I., Borja, A., Pascual, A., Rodríguez-Lázaro, J., Donard, O., 2008. Recent sedimentary study of the shelf of the Basque country. Journal of Marine Systems, Oceanography of the Bay of Biscay 72, 397-406. https://doi.org/10.1016/j.jmarsys.2007.03.013

Jouanneau, J.M., Weber, O., Cremer, M., Castaing, P., 1999. Fine-grained sediment budget on the continental margin of the Bay of Biscay. Deep Sea Research Part II: Topical Studies in Oceanography 46, 2205-2220. https://doi.org/10.1016/S0967-0645(99)00060-0

Jouanneau, J.M., Weber, O., Drago, T., Rodrigues, A., Oliveira, A., Dias, J.M.A., Garcia, C., Schmidt, S., Reyss, J.L., 2002. Recent sedimentation and sedimentary budgets on the western Iberian shelf. Progress in Oceanography, Benthic processes and dynamics at the NW Iberian Margin: results of the OMEX II Program 52, 261-275. https://doi.org/10.1016/S0079-6611(02)00010-1

Jouanneau, J.M., Weber, O., Latouche, C., Vernet, J.P., Dominik, J., 1989. Erosion, nondeposition and sedimentary processes through a sedimentological and radioisotopic study of surficial deposits from the "Ouest-Gironde vasière" (Bay of Biscay). Continental Shelf Research 9, 325-342. https://doi.org/10.1016/0278-4343(89)90037$\mathrm{X}$

Keil, R., 2017. Anthropogenic Forcing of Carbonate and Organic Carbon Preservation in Marine Sediments. Annual Review of Marine Science 9, 151-172. https://doi.org/10.1146/annurev-marine-010816-060724

Kuehl, S.A., DeMaster, D.J., Nittrouer, C.A., 1986. Nature of sediment accumulation on the Amazon continental shelf. Continental Shelf Research 6, 209-225. https://doi.org/10.1016/0278-4343(86)90061-0

Kuzyk, Z.Z.A., Gobeil, C., Goñi, M.A., Macdonald, R.W., 2017. Early diagenesis and trace element accumulation in North American Arctic margin sediments. Geochimica et Cosmochimica Acta 203, 175-200. https://doi.org/10.1016/j.gca.2016.12.015

Leithold, E.L., Perkey, D.W., Blair, N.E., Creamer, T.N., 2005. Sedimentation and carbon burial on the northern California continental shelf: the signatures of land-use change. Continental Shelf Research 25, 349-371. https://doi.org/10.1016/j.csr.2004.09.015

Lesueur, P., Jouanneau, J.-M., Boust, D., Tastet, J.-P., Weber, O., 2001. Sedimentation rates and fluxes in the continental shelf mud fields in the Bay of Biscay (France). Continental Shelf Research 21, 1383-1401. https://doi.org/10.1016/S0278-4343(01)00004-8

Lesueur, P., Tastet, J.P., Marambat, L., 1996. Shelf mud fields formation within historical times: examples from offshore the Gironde estuary, France. Continental Shelf Research 16, 1849-1870. https://doi.org/10.1016/0278-4343(96)00013-1

Lesueur, P., Tastet, J.P., Weber, O., 2002. Origin and morphosedimentary evolution of finegrained modern continental shelf deposits: the Gironde mud fields (Bay of Biscay, France). Sedimentology 49, 1299-1320. https://doi.org/10.1046/j.13653091.2002.00498.x

Lesueur, P., Tastet, J.-P., Weber, O., Sinko, J.-A., 1991. Modèle faciologique d'un corps sédimentaire pélitique de plate-forme: la vasière Ouest-Gironde (France). Oceanologica Acta sp., 143-153.

Lofi, J., Werber, O., 2001. SCOPIX - digital processing of X-ray images for the enhancement of sedimentary structures in undisturbed core slabs. Geo-Marine Letters 20, 182-186. https://doi.org/10.1007/s003670000051

Masqué, P., Isla, E., Sanchez-Cabeza, J.A., Palanques, A., Bruach, J.M., Puig, P., Guillén, J., 2002. Sediment accumulation rates and carbon fluxes to bottom sediments at the Western Bransfield Strait (Antarctica). Deep Sea Research Part II: Topical Studies in Oceanography, FRUELA - A Carbon Flux Study in the Antarctic Peninsula Area 49, 921-933. https://doi.org/10.1016/S0967-0645(01)00131-X 
Massé, C., Meisterhans, G., Deflandre, B., Bachelet, G., Bourasseau, L., Bichon, S., Ciutat, A., Jude-Lemeilleur, F., Lavesque, N., Raymond, N., Grémare, A., Garabetian, F., 2016. Bacterial and macrofaunal communities in the sediments of the West Gironde Mud Patch, Bay of Biscay (France). Estuarine, Coastal and Shelf Science, Special Issue: Functioning and dysfunctioning of Marine and Brackish Ecosystems 179, 189-200. https://doi.org/10.1016/j.ecss.2016.01.011

Mayer, L.M., 1994a. Surface area control of organic carbon accumulation in continental shelf sediments. Geochimica et Cosmochimica Acta 58, 1271-1284. https://doi.org/10.1016/0016-7037(94)90381-6

Mayer, L.M., 1994b. Relationships between mineral surfaces and organic carbon concentrations in soils and sediments. Chemical Geology 114, 347-363. https://doi.org/10.1016/0009-2541(94)90063-9

McCave, I.N., 1972. Shelf Sediment Transport, Process and Pattern, in: Swift, D.J.P., Duane, D.B., Pilkey, O.H. (Eds.), Transport and Escape of Fine-Grained Sediment from Shelf Areas. Dowden, Hutchinson \& Ross, Stroudsburg, Pa., pp. 225-248.

McKee, B.A., Aller, R.C., Allison, M.A., Bianchi, T.S., Kineke, G.C., 2004. Transport and transformation of dissolved and particulate materials on continental margins influenced by major rivers: benthic boundary layer and seabed processes. Continental Shelf Research 24, 899-926. https://doi.org/10.1016/j.csr.2004.02.009

Middelburg, J.J., 2019. Carbon Processing at the Seafloor, in: China's Provincial Economic Competitiveness and Policy Outlook for the 13th Five-Year Plan Period (2016-2020). Springer Singapore, Singapore, pp. 57-75. https://doi.org/10.1007/978-3-030-108229_4

Mouret, A., Anschutz, P., Deflandre, B., Chaillou, G., Hyacinthe, C., Deborde, J., Etcheber, H., Jouanneau, J.-M., Grémare, A., Lecroart, P., 2010. Oxygen and organic carbon fluxes in sediments of the Bay of Biscay. Deep Sea Research Part I: Oceanographic Research Papers 57, 528-540. https://doi.org/10.1016/j.dsr.2009.12.009

Muller-Karger, F.E., 2005. The importance of continental margins in the global carbon cycle. Geophysical Research Letters 32, L01602. https://doi.org/10.1029/2004GL021346

Pastor, L., Cathalot, C., Deflandre, B., Viollier, E., Soetaert, K., Meysman, F.J.R., Ulses, C., Metzger, E., Rabouille, C., 2011. Modeling biogeochemical processes in sediments from the Rhône River prodelta area (NW Mediterranean Sea). Biogeosciences 8, 13511366. https://doi.org/10.5194/bg-8-1351-2011

Pastor, L., Rabouille, C., Metzger, E., Thibault de Chanvalon, A., Viollier, E., Deflandre, B., 2018. Transient early diagenetic processes in Rhône prodelta sediments revealed in contrasting flood events. Continental Shelf Research 166, 65-76. https://doi.org/10.1016/j.csr.2018.07.005

Qiao, S., Shi, X., Wang, G., Zhou, L., Hu, B., Hu, L., Yang, G., Liu, Y., Yao, Z., Liu, S., 2017. Sediment accumulation and budget in the Bohai Sea, Yellow Sea and East China Sea. Marine Geology 390, 270-281. https://doi.org/10.1016/j.margeo.2017.06.004

Relexans, J.-C., Lin, R.G., Castel, J., Etcheber, H., Laborde, P., 1992. Response of biota to sedimentary organic matter quality of the West Gironde mud patch, Bay of Biscay (France). Oceanologica Acta 15, 639-649.

Schmidt, S., 2020. Depth profiles of selected radionuclides and grain size in marine sediments of the West Gironde Mud Patch (Bay of Biscay). https://doi.org/10.17882/77523

Schmidt, S., Howa, H., Diallo, A., Martín, J., Cremer, M., Duros, P., Fontanier, C., Deflandre, B., Metzger, E., Mulder, T., 2014. Recent sediment transport and deposition in the CapFerret Canyon, South-East margin of Bay of Biscay. Deep Sea Research Part II: Topical Studies in Oceanography 104, 134-144. https://doi.org/10.1016/j.dsr2.2013.06.004 
Schmidt, S., Howa, H., Mouret, A., Lombard, F., Anschutz, P., Labeyrie, L., 2009. Particle fluxes and recent sediment accumulation on the Aquitanian margin of Bay of Biscay. Continental Shelf Research, 100 Years of Research within the Bay of Biscay 29, 10441052. https://doi.org/10.1016/j.csr.2008.11.018

Sun, X., Fan, D., Liu, M., Liao, H., Tian, Y., 2020. The fate of organic carbon burial in the river-dominated East China Sea: Evidence from sediment geochemical records of the last 70 years. Organic Geochemistry 143, 103999. https://doi.org/10.1016/j.orggeochem.2020.103999

van Weering, T.C.E., de Stigter, H.C., Boer, W., de Haas, H., 2002. Recent sediment transport and accumulation on the NW Iberian margin. Progress in Oceanography, Benthic processes and dynamics at the NW Iberian Margin: results of the OMEX II Program 52, 349-371. https://doi.org/10.1016/S0079-6611(02)00015-0

van Weering, Tj.C.E., Hall, I.R., de Stigter, H.C., McCave, I.N., Thomsen, L., 1998. Recent sediments, sediment accumulation and carbon burial at Goban Spur, N.W. European Continental Margin $\left(47-50^{\circ} \mathrm{N}\right)$. Progress in Oceanography 42, 5-35. https://doi.org/10.1016/S0079-6611(98)00026-3

Walsh, J.P., Nittrouer, C.A., 2009. Understanding fine-grained river-sediment dispersal on continental margins. Marine Geology 263, 34-45. https://doi.org/10.1016/j.margeo.2009.03.016

Weber, O., Jouanneau, J.M., Ruch, P., Mirmand, M., 1991. Grain-size relationship between suspended matter originating in the Gironde estuary and shelf mud-patch deposits. Marine Geology 96, 159-165. https://doi.org/10.1016/0025-3227(91)90213-N

Włodarska- Kowalczuk, M., Mazurkiewicz, M., Górska, B., Michel, L.N., Jankowska, E., Zaborska, A., 2019. Organic Carbon Origin, Benthic Faunal Consumption, and Burial in Sediments of Northern Atlantic and Arctic Fjords $\left(60-81^{\circ} \mathrm{N}\right)$. Journal of Geophysical Research: Biogeosciences 124, 3737-3751. https://doi.org/10.1029/2019JG005140

Yao, P., Zhao, B., Bianchi, T.S., Guo, Z., Zhao, M., Li, D., Pan, H., Wang, J., Zhang, T., Yu, Z., 2014. Remineralization of sedimentary organic carbon in mud deposits of the Changjiang Estuary and adjacent shelf: Implications for carbon preservation and authigenic mineral formation. Continental Shelf Research 91, 1-11. https://doi.org/10.1016/j.csr.2014.08.010

Zhu, C., Wagner, T., Talbot, H.M., Weijers, J.W.H., Pan, J.-M., Pancost, R.D., 2013. Mechanistic controls on diverse fates of terrestrial organic components in the East China Sea. Geochimica et Cosmochimica Acta 117, 129-143. https://doi.org/10.1016/j.gca.2013.04.015

Zhu, M.-X., Chen, K.-K., Yang, G.-P., Fan, D.-J., Li, T., 2016. Sulfur and iron diagenesis in temperate unsteady sediments of the East China Sea inner shelf and a comparison with tropical mobile mud belts (MMBs): S and Fe Diagenesis in Sediments. Journal of Geophysical Research: Biogeosciences 121, 2811-2828. https://doi.org/10.1002/2016JG003391 


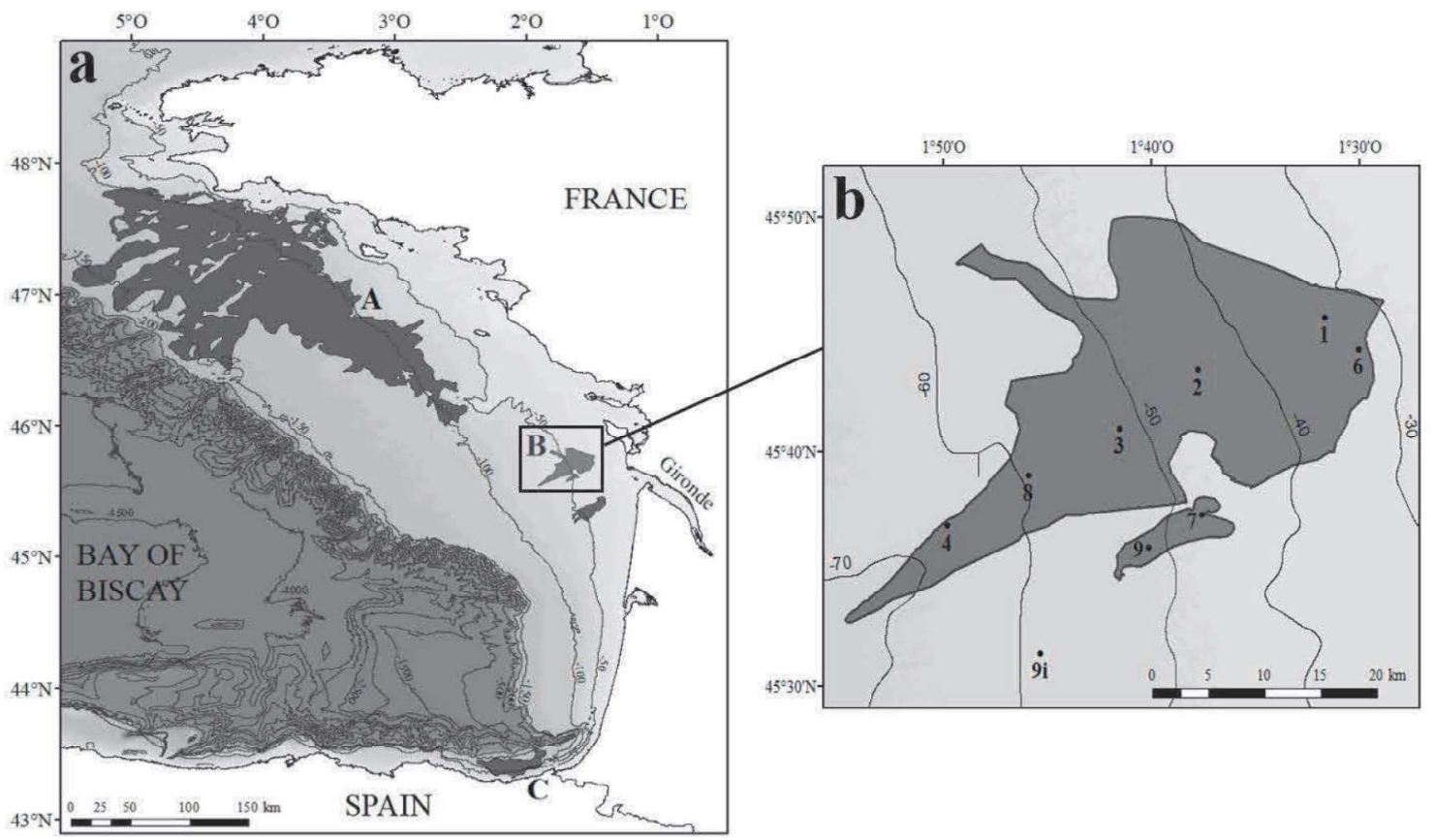

Figure 1: (a) Map of the Bay of Biscay continental shelf with the locations of mud belts and patches: A - La Grande Vasière, B - The Gironde Mud Patches, and C - The Basque Mud Patch. (b) Map of the WGMP showing the location of sampling stations (black circles). The synoptic map of the West Gironde Mud Patch has been determined during the JERICOBENT-5TH cruise (Gillet and Deflandre, 2018) 


\section{Northern transect}

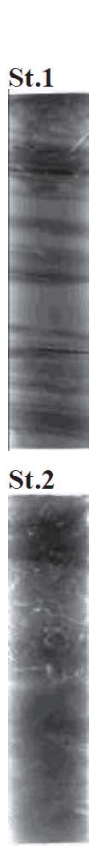

St.3

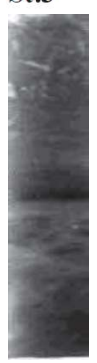

St.8

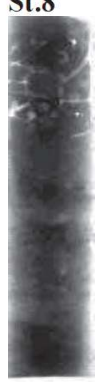

St.4

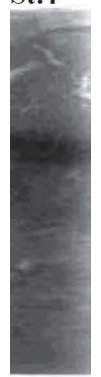

DBD $\left(\mathrm{mg} \mathrm{cm}^{-3}\right)$

D50 $(\mu \mathrm{m})$

$\begin{array}{lllllllll}0.0 & 0.5 & 1.0 & 1.5 & 0 & 25 & 50 & 75 & 100\end{array}$

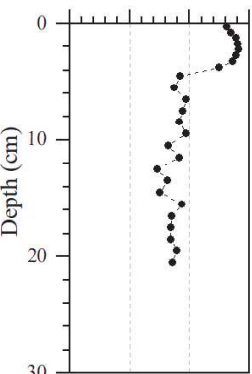

301
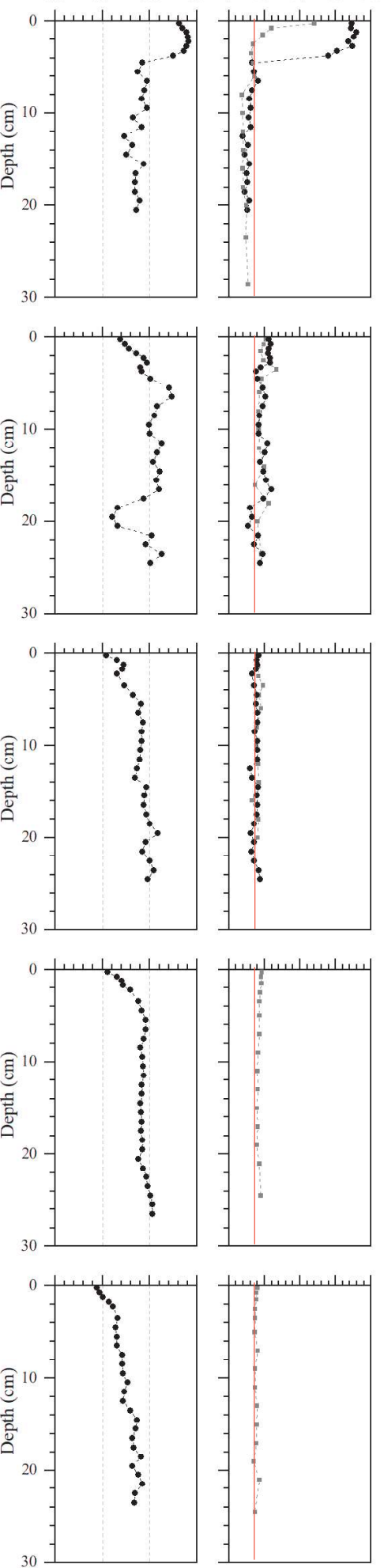

St.9i

Southern transect

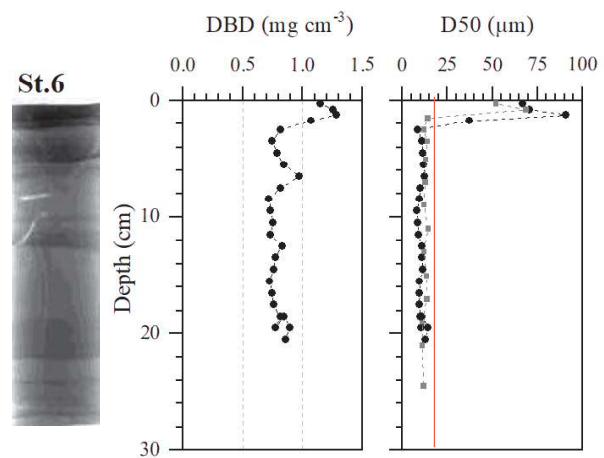

St. 7
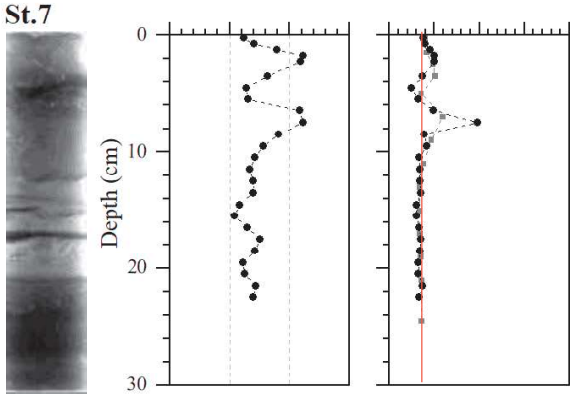

St.9
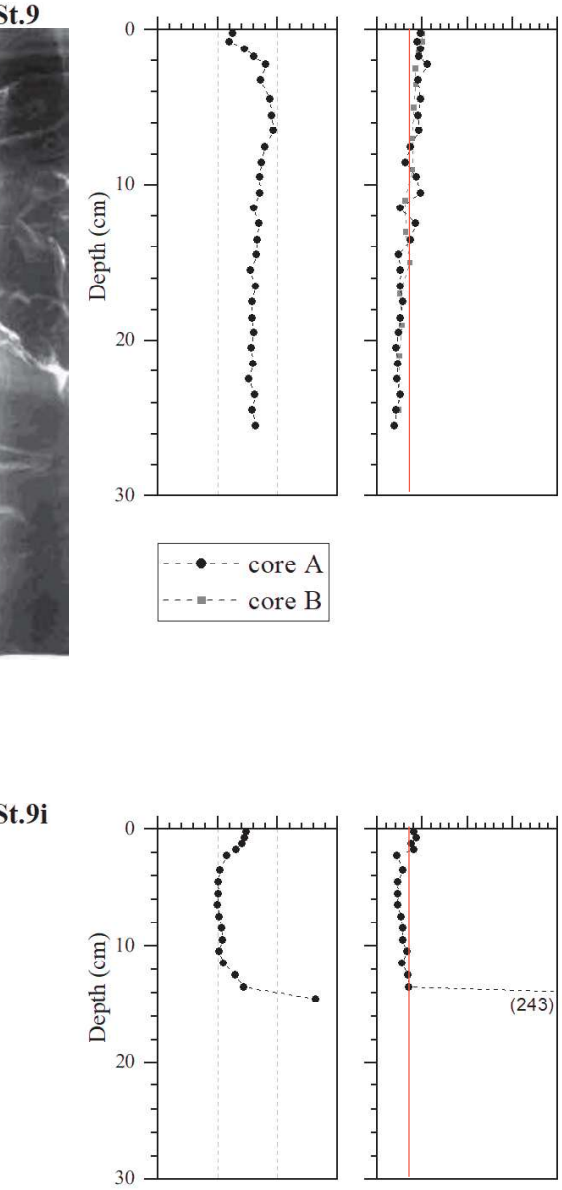

Figure 2: Sedimentary structures: X-ray images and profiles of dry bulk density and median grain-size with depth of cores collecting along the northern (left) and southern (right) transects. The red line defines the background grain-size ( $20 \mu \mathrm{m})$, and in some cases higher sand content is observed $(>6 \%)$. 


\section{Northern transect}

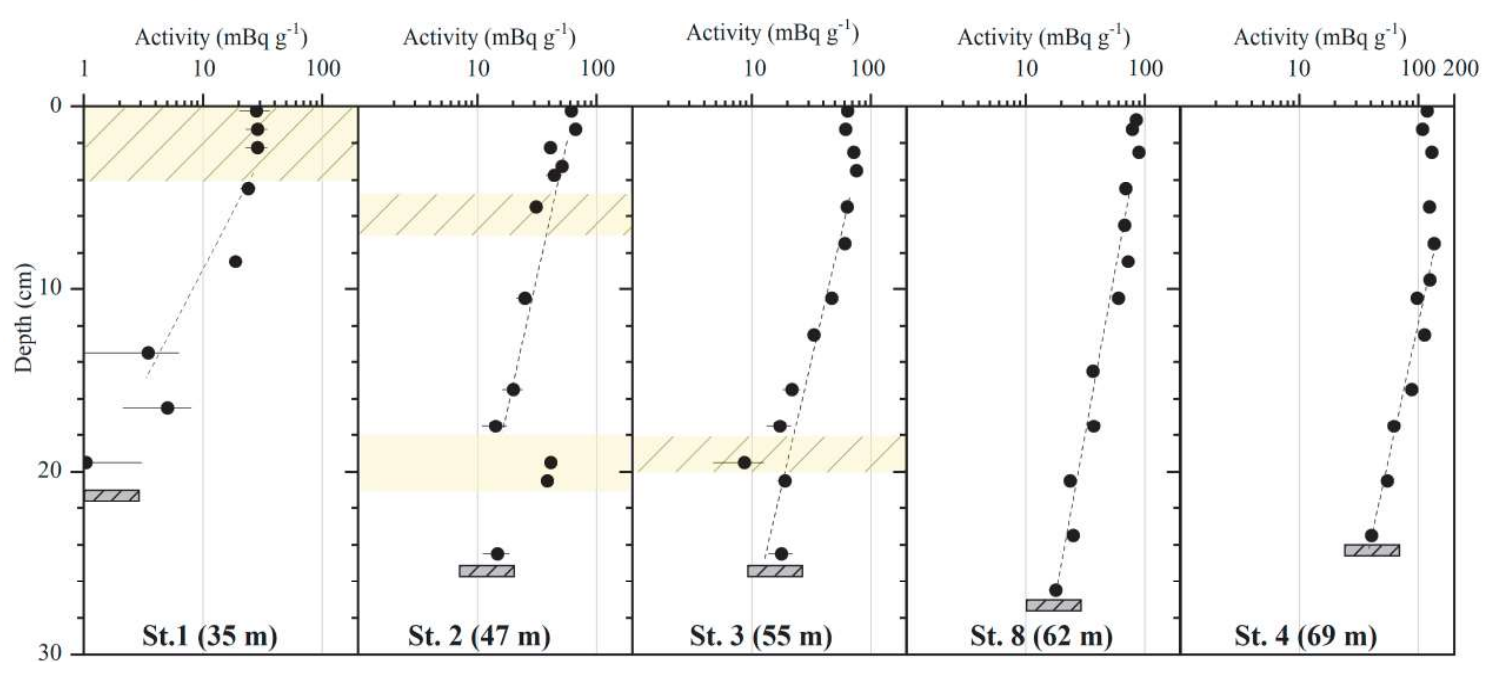

\section{Southern transect}

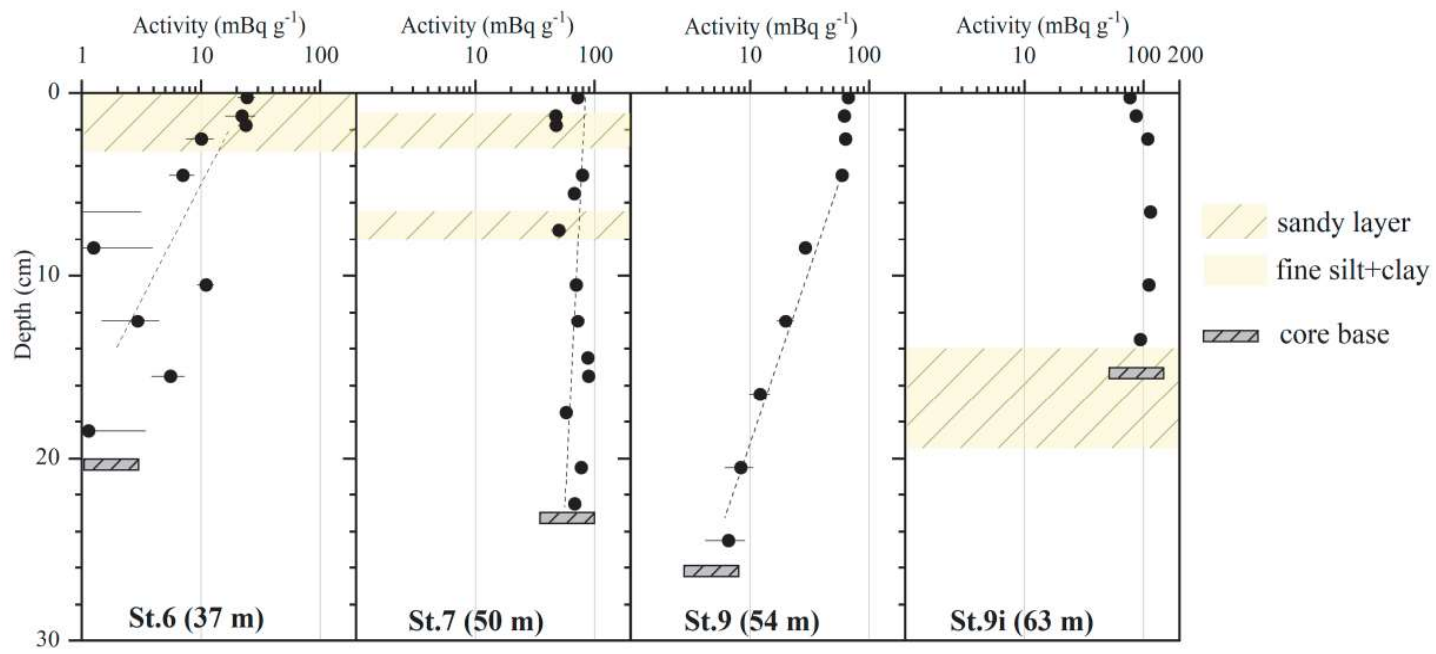

Figure 3: Depth profiles of ${ }^{210} \mathrm{~Pb}_{\mathrm{xs}}$ activity for all the sediment cores collected in the West Gironde Mud Patch in fall 2016. Next to the core label, numbers are the water depth at which the cores were collected. Errors bars correspond to $1 \mathrm{SD}$. The grey rectangle indicates the length of the core. 
Table 1: Mean bottom OC contents, sediment (SAR) and mass (MAR) accumulation rates calculated from ${ }^{210} \mathrm{~Pb}_{\mathrm{xs}}$ profiles and calculated OC burial rates at nine sites of the West Gironde Mud Patch. For stations 1, 6 and 9, the bottom OC values were taken at the base of modern sediments (see Figure 4)

\begin{tabular}{|c|c|c|c|c|c|c|c|c|c|}
\hline Transect & Stations & $\begin{array}{l}\text { Lat. } \\
{ }^{\circ} \mathrm{N}\end{array}$ & $\begin{array}{c}\text { Long. } \\
{ }^{\circ} \mathrm{E}\end{array}$ & $\begin{array}{c}\text { Depth } \\
\text { m }\end{array}$ & $\begin{array}{c}\text { Bottom OC } \\
\%\end{array}$ & $n=$ & $\begin{array}{c}\text { SAR } \\
\mathrm{cm} \mathrm{yr}^{-1}\end{array}$ & $\begin{array}{c}\text { MAR } \\
\mathrm{mg} \mathrm{cm}^{-2} \mathrm{yr}^{-1}\end{array}$ & $\begin{array}{c}\text { OC burial } \\
\text { rates } \\
\mathrm{gC} \mathrm{m}^{-2} \mathrm{yr}^{-1}\end{array}$ \\
\hline \multirow{5}{*}{ North } & 1 & $45^{\circ} 45^{\prime} 38^{\prime \prime}$ & $-1^{\circ} 31^{\prime} 41^{\prime \prime}$ & 35 & $0.64 \pm 0.03 *$ & 1 & $0.14 \pm 0.08 * *$ & $126 \pm 73^{* *}$ & $8 \pm 5^{* *}$ \\
\hline & 2 & $45^{\circ} 43^{\prime} 45^{\prime \prime}$ & - 1³7'57" & 47 & $0.66 \pm 0.20$ & 5 & $0.48 \pm 0.09 * *$ & $486 \pm 89 * *$ & $32 \pm 16$ \\
\hline & 3 & $45^{\circ} 40^{\prime} 58^{\prime \prime}$ & - $1^{\circ} 41^{\prime} 30^{\prime \prime}$ & 55 & $0.99 \pm 0.12$ & 5 & $0.38 \pm 0.04$ & $361 \pm 35$ & $36 \pm 8$ \\
\hline & 8 & $45^{\circ} 38^{\prime} 55^{\prime \prime}$ & - $1^{\circ} 45^{\prime} 48^{\prime \prime}$ & 62 & $1.02 \pm 0.02$ & 5 & $0.47 \pm 0.05$ & $438 \pm 47$ & $45 \pm 6$ \\
\hline & 4 & $45^{\circ} 36^{\prime} 50^{\prime \prime}$ & - $1^{\circ} 49^{\prime} 47^{\prime \prime}$ & 69 & $1.30 \pm 0.04$ & 4 & $0.41 \pm 0.07$ & $338 \pm 56$ & $44 \pm 9$ \\
\hline \multirow{4}{*}{ South } & 6 & $45^{\circ} 44^{\prime} 22^{\prime \prime}$ & $-1^{\circ} 30^{\prime} 2^{\prime \prime}$ & 37 & $0.42 \pm 0.27$ & 2 & $0.22 \pm 0.13 * *$ & $172 \pm 102 * *$ & $7 \pm 9 * *$ \\
\hline & 7 & $45^{\circ} 37^{\prime} 17^{\prime \prime}$ & - 1³7'34" & 50 & $1.41 \pm 0.19$ & 6 & $0.97 \pm 0.20 * * *$ & $648 \pm 122 * * *$ & - \\
\hline & 9 & $45^{\circ} 35^{\prime} 54^{\prime \prime}$ & $-1^{\circ} 40^{\prime} 9^{\prime \prime}$ & 54 & $1.17 \pm 0.10$ & 3 & $0.29 \pm 0.03$ & $237 \pm 22$ & $28 \pm 5$ \\
\hline & $9 \mathrm{i}$ & $45^{\circ} 31^{\prime} 25^{\prime \prime}$ & - $1^{\circ} 45^{\prime} 20^{\prime \prime}$ & 63 & - & - & $2.83 * * *$ & $1413 * * *$ & - \\
\hline
\end{tabular}

*analytical incertitude

** apparent maximum SAR, MAR and OC burial rates, presence of sandy layers

*** indicative maximum SAR and MAR - not suitable for calculations 


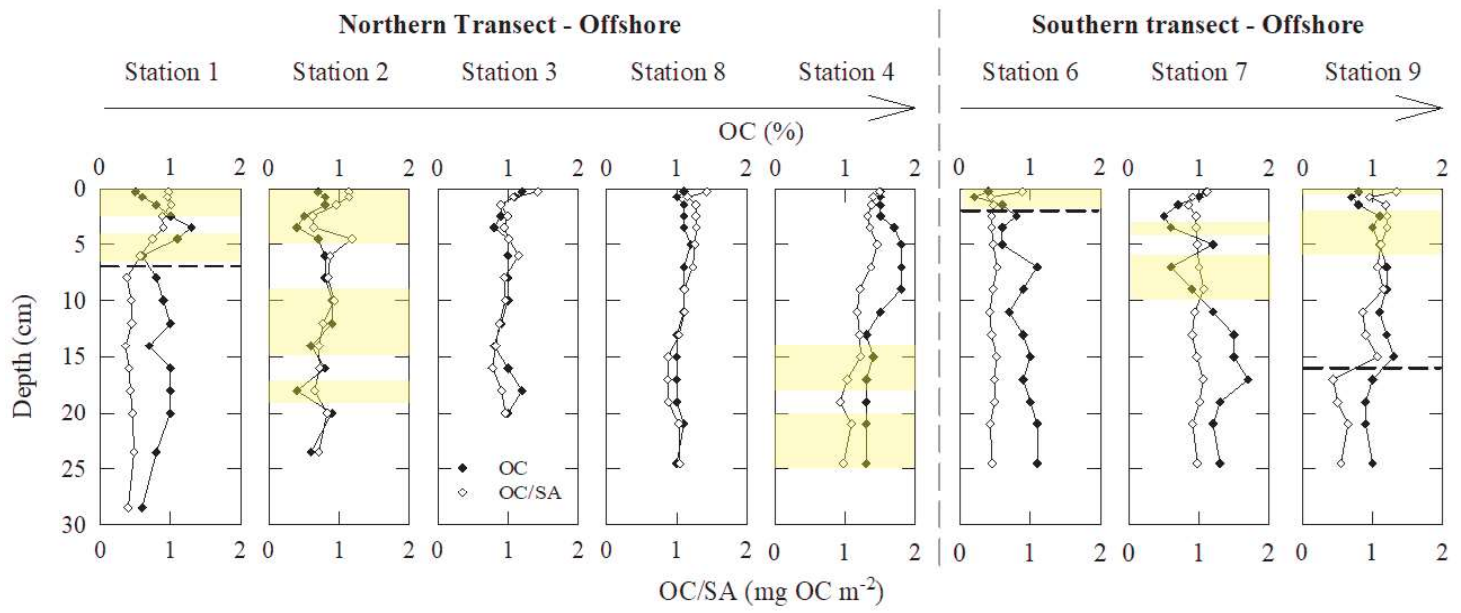

Figure 4: Vertical distributions of $\mathrm{OC}$ content $(\%)$ and $\mathrm{OC} / \mathrm{SA}$ ratio $\left(\mathrm{mgOC} \mathrm{m}^{-2}\right)$ in sediment cores collected in the West Gironde Mud Patch. The yellow stripes indicate the position of noticeable sandy layers. Dashed lines represent the limit between modern and relic deposits. 
Table 2: Surface and bottom core OC contents $(\%)$ and OC/SA ratio $\left(\mathrm{mgOC} \mathrm{m}^{-2}\right)$. ${ }^{*}$ For stations 1,6 and 9 the bottom values were taken at the base of modern sediments.

\begin{tabular}{cccccc}
\hline \multirow{2}{*}{ Stations (Depth) } & \multicolumn{2}{c}{ OC content (\%) } & \multicolumn{2}{c}{ OC/SA $\left(\mathrm{mgOC} \mathrm{m}^{-2}\right)$} \\
& & Surface & Bottom & Surface & Bottom \\
\hline \multirow{4}{*}{ North } & $1(35 \mathrm{~m})$ & 0.48 & $0.64^{*}$ & 0.97 & $0.57^{*}$ \\
& $2(47 \mathrm{~m})$ & 0.70 & 0.56 & 1.14 & 0.71 \\
& $3(55 \mathrm{~m})$ & 1.15 & 1.02 & 1.42 & 0.96 \\
& $8(62 \mathrm{~m})$ & 1.08 & 1.01 & 1.43 & 1.04 \\
& $4(69 \mathrm{~m})$ & 1.53 & 1.25 & 1.49 & 0.98 \\
& & & & & \\
\multirow{3}{*}{ South } & $7(37 \mathrm{~m})$ & 0.36 & $0.61 *$ & 0.89 & $0.48^{*}$ \\
& $7(50 \mathrm{~m})$ & 1.09 & 1.32 & 1.12 & 0.98 \\
\hline
\end{tabular}



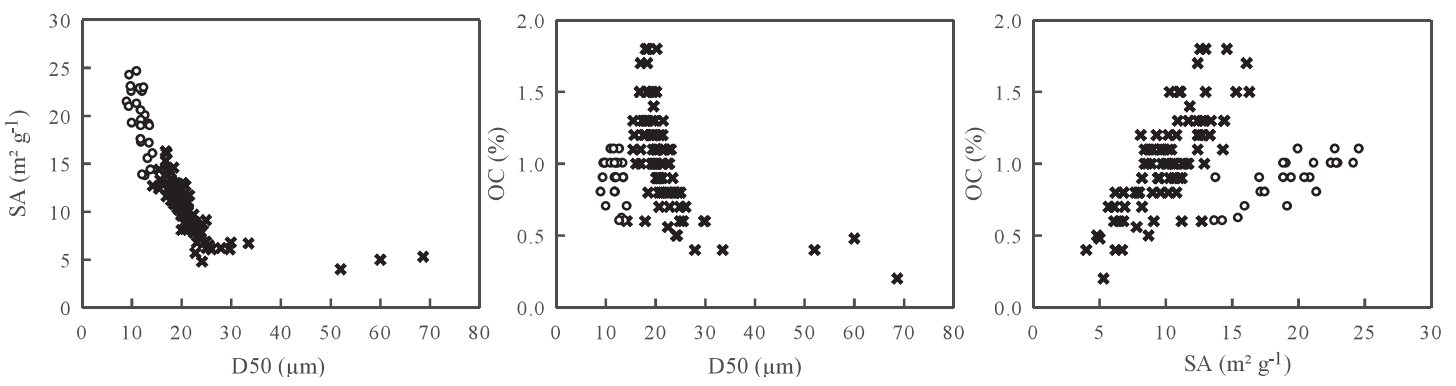

Figure 5: SA against median grain-size (a), sediment OC content against median grain-size (b) and SA (c). Cross correspond to all the sediment samples, excluding the relic sediments (white circles; stations 1,6 and 9). 

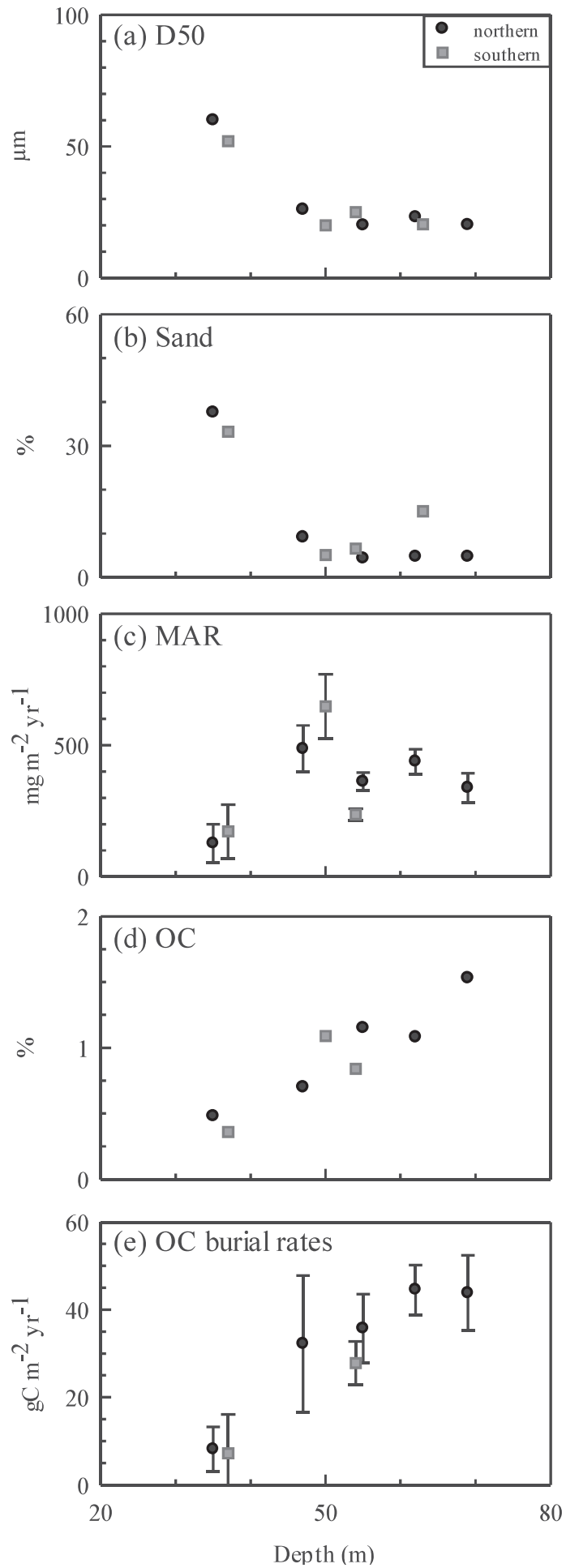

Figure 6: Median grain-size (a), sand (b) and organic carbon (d) content of surface sediments, mass accumulation rates (c) and OC burial rates at multi-decennial scales (e) against water depth of stations along the northern and the southern transects of the West Gironde Mud Patch. 


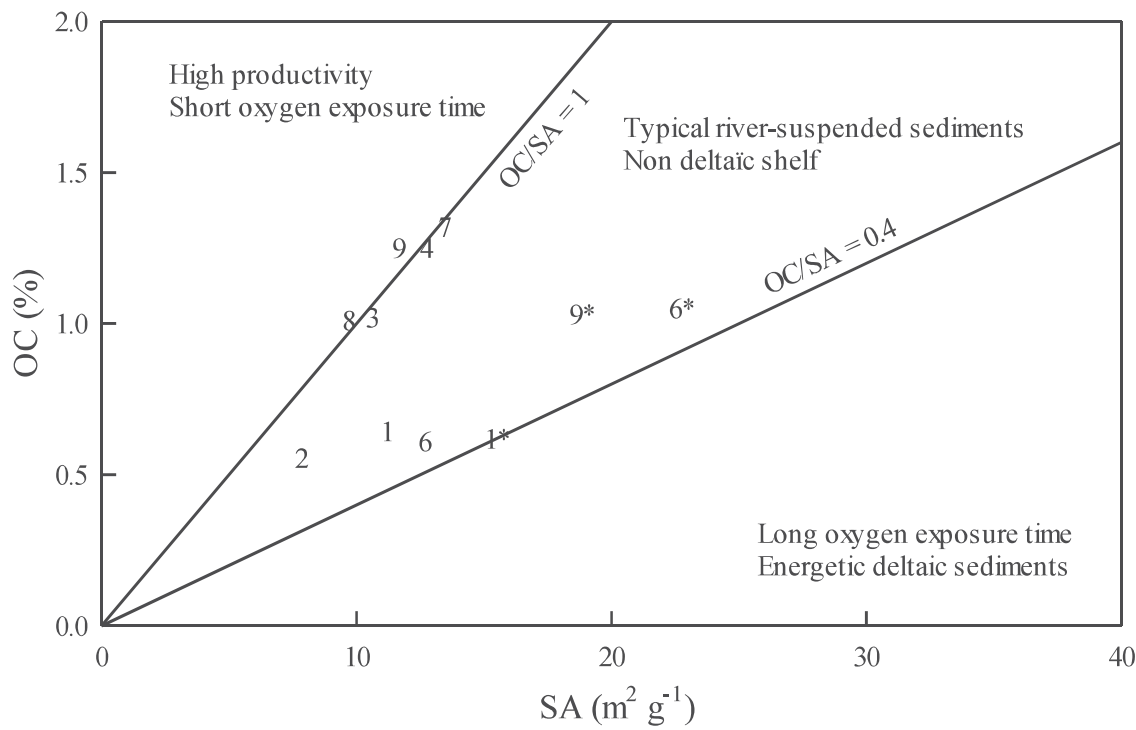

Figure 7: Relationship of OC contents (\%) against surface areas of sediments $\left(\mathrm{SA} ; \mathrm{m}^{2} \mathrm{~g}^{-1}\right)$ at the base of modern and relic (*) sediments of the West Gironde Mud Patch. Adapted from Blair and Aller (2012). 
Table 3: Mass accumulation rates and OC burial rates in sediments of (1) the West Gironde Mud Patch (this study) (2) the Bay of Biscay (Mouret et al., 2010), (3) the Goban Spur (Celtic margin, Van Weering et al., 1998), (4) the Iberian Margin (Van Weering et al., 2002), (5) the Gulf of Lions shelf (Accornero et al., 2003) and of (6) the Amazon deltaic shelf (Aller et al., 1996; Kuehl et al., 1986), the Bohai and Yellow Seas (Hu et al., 2016), the Zhejiang-Fujian Mud Zone (East China Sea, Sun et al., 2020), the inner Louisiana shelf (Gordon et al., 2001). The most proximal sites of the WGMP (i.e., 1 and 6) are not considered. *Average values of organic carbon burial rates.

\begin{tabular}{|c|c|c|c|c|}
\hline Location & $\begin{array}{l}\text { Depth } \\
\text { (m) }\end{array}$ & $\begin{array}{c}\text { MAR } \\
\left(\mathrm{mg} \mathrm{cm}^{-2} \mathrm{yr}^{-1}\right)\end{array}$ & $\begin{array}{c}\text { OC burial rates } \\
\qquad\left(\mathrm{gC} \mathrm{m}^{-2} \mathrm{yr}^{-1}\right)\end{array}$ & References \\
\hline WGMP (Bay of Biscay) & $47-69$ & $237-486$ & $28-45$ & This study \\
\hline Bay of Biscay & 550 & 78 & 7.32 & \\
\hline Bay of Biscay & 1000 & 36 & 2.52 & \\
\hline Bay of Biscay & 1250 & 44 & 2.4 & Mouret et al. (2010) \\
\hline Bay of Biscay & 1500 & 7 & 0.45 & \\
\hline Bay of Biscay & 2000 & 14 & 0.96 & \\
\hline Goban Spur & 208 & $<5.8$ & $>0.16$ & Van Weering et al. (1998) \\
\hline Iberian Margin & 104 & 204.2 & 34.30 & \\
\hline Iberian Margin & 123 & 208.9 & 9.00 & \\
\hline Iberian Margin & 199 & 150.1 & 7.09 & Van Weering et al. (2002) \\
\hline Iberian Margin & 223 & 157.1 & 5.02 & \\
\hline Iberian Margin & 343 & 63.4 & 3.77 & \\
\hline Gulf of Lions & 87 & 230 & 19.0 & Accornero et al. (2003) \\
\hline Amazon deltaic shelf & $9-53$ & $100-6900$ & $58.3^{*}$ & Aller et al. (1996), Kuehl et al. (1986) \\
\hline Bohai and Yellow Seas & $0-400$ & $<100-7000$ & $15.3 *$ & Hu et al. (2016) \\
\hline East China Sea & 45.4 & $200-700$ & $41.2^{*}$ & Sun et al. (2020) \\
\hline Louisiana shelf & $4-23$ & $120-450$ & $22.7^{*}$ & Gordon et al. (2001) \\
\hline
\end{tabular}




\section{Declaration of interests}

$\bigotimes$ The authors declare that they have no known competing financial interests or personal relationships that could have appeared to influence the work reported in this paper.

$\square$ The authors declare the following financial interests/personal relationships which may be considered as potential competing interests:

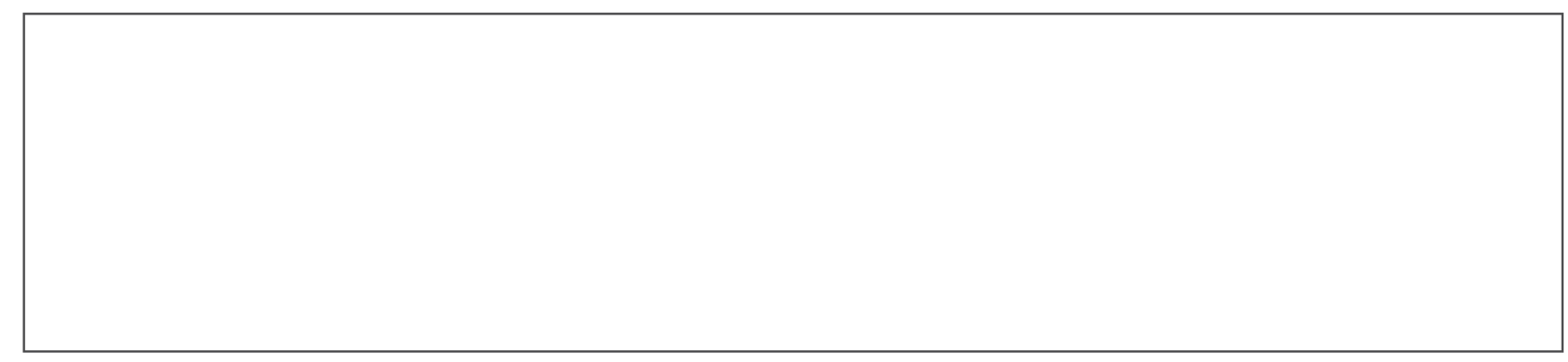

